Veiling in Style: How Does a Stigmatized Practice Become Fashionable?

Author(s): Özlem Sandikci and Güliz Ger

Source: Journal of Consumer Research, Vol. 37, No. 1 (June 2010), pp. 15-36

Published by: Oxford University Press

Stable URL: http://www.jstor.org/stable/10.1086/649910

Accessed: 29-08-2017 12:37 UTC

JSTOR is a not-for-profit service that helps scholars, researchers, and students discover, use, and build upon a wide range of content in a trusted digital archive. We use information technology and tools to increase productivity and facilitate new forms of scholarship. For more information about JSTOR, please contact support@jstor.org.

Your use of the JSTOR archive indicates your acceptance of the Terms \& Conditions of Use, available at http://about.jstor.org/terms

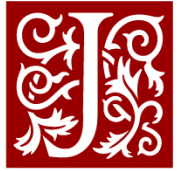

Oxford University Press is collaborating with JSTOR to digitize, preserve and extend access to Journal of Consumer Research 


\title{
Veiling in Style: How Does a Stigmatized Practice Become Fashionable?
}

\author{
ÖZLEM SANDIKCI \\ GÜLIZ GER
}

\begin{abstract}
Although stigma is prevalent in everyday life, consumer researchers' interest on the topic remains scant and focuses mostly on stigma management. We move beyond individual coping strategies and examine the processes of stigmatization and destigmatization. Through an ethnographic study of fashion consumption practices of urban Turkish covered women, we explore how veiling, a deviant practice stigmatized in the secular and urban mind-set, first became an attractive choice for some middle-class women and then transformed into a fashionable and ordinary clothing practice for many. We map out the global multi-actored work that underlies the emergence of veiling as an attractive choice and explicate its gradual routinization and destigmatization. We discuss the findings in terms of their implications for understandings of choice and free will, the formative role of fashion in the evolution of a new habitus and social class, and the relationship between the market and religion.
\end{abstract}

$\mathrm{W}$ e are unlikely to encounter Star Trek fans dressed as Trekkies at a business meeting. However, some deviant practices that were once marginal and stigmatized can over time become fashionable and ordinary consumption choices. Consider, for example, wearing blue jeans and getting tattoos. We no longer associate jeans with hoodlum motorcycle gangs (Davis 1989) and tattoos with intimidating ex-convicts (DeMello 2000). Each of these products, once attractive only for a particular group of consumers, now appeals, in a variety of configurations, to the general public. Such changes in the status of practices highlight the socially constructed nature of what we regard as a "normal" or "deviant" consumption choice at a particular sociotemporal context and remind us that what appears to be an ordinary consumption practice today might entail in its historical trajectory a significant amount of negotiation and constructive work. From the consumer's point of view, getting tattoos, wearing jeans, and dressing as a Trekkie, unlike being of a particular ethnicity, are practices s/he volitionally chooses to engage in or not. But then, how and why do consumers voluntarily choose a stigmatized practice, how and why do

Özlem Sandıkcı is assistant professor of marketing, Bilkent University, Ankara 06800, Turkey (sandikci@bilkent.edu.tr). Güliz Ger is professor of marketing, Bilkent University, Ankara 06800, Turkey (ger@bilkent .edu.tr). The authors thank Sidney Levy for his comments and the informants for sharing their experiences. The authors also acknowledge the valuable insights provided by the editor, associate editor, and reviewers.

John Deighton served as editor and Eric Arnould served as associate editor for this article.

Electronically published December 16, 2009 these practices become fashionable and ordinary consumption choices, and why do only some of these practices become so?

Despite its prevalence and relevance, consumer researchers' interest on stigma remains scant and focuses mostly on stigma management (Adkins and Ozanne 2005; Argo and Main 2008; Henry and Caldwell 2006; Tepper 1994). These studies identify various coping strategies that consumers use in order to deal with the negative effects of stigma. However, they offer little information on adoption (choosing a stigmatized practice) and transformation (change in the stigma status) processes. Although not addressing stigma directly, research on consumption collectivities (Goulding et al. 2009; Kates 2002; Kozinets 2001, 2002; Muñiz and O'Guinn 2000; Muñiz and Schau 2005; Schouten and McAlexander 1995) provide some insights into these issues. This literature suggests that consumers may choose to engage in a deviant practice in order to express their opposition to mainstream norms and/or escape from various daily personal problems; however, it does not explicate how a deviant practice becomes an attractive consumption choice in the first place. In regard to the change in the status of a deviant practice, some studies suggest that transformation happens through market co-optation (Bengtsson, Ostberg, and Kjeldgaard 2005; Goulding et al. 2009; Kozinets 2001; Schouten and McAlexander 1995; Thompson and Coşkuner-Ballı 2007). That is, a marginal, subcultural practice becomes popular when the market appropriates and commercializes it. However, except Goulding et al.'s (2009) analysis of marketization of rave and Schouten and McAlexander's (1995) discussion of the Harley-Davidson company's expropriation of 
certain symbols of the outlaw subculture, research tends to focus more on understanding how a subcultural group resists and negotiates mainstreaming rather than how co-optation actually happens. Furthermore, whether there are other mechanisms besides co-optation through which change might happen remains unknown.

Thus, the processes of adoption and transformation are largely unstudied. The lack is perhaps due to a scarcity of historical analyses, which are necessary for mapping out a process and perhaps, in the specific case of the stigma literature, due to an emphasis on the individual effects of stigma rather than its sociocultural underpinnings. Our goal in this research is to interrogate the processes through which a stigmatized consumption practice is chosen and through which its stigma status might change. Specifically, we explore four key questions: How and why does a stigmatized practice become a consumption choice in the first place? What are the mechanisms underlying the transformation in the stigma status of this practice? What roles do consumers, the market, and other individual and institutional participants play in adoption and transformation processes? And, what are the personal, societal, and theoretical ramifications of these processes?

Our context is Islamic veiling in Turkey. Veiling, a practice laden with stigmatization in the Western mind-set (Göle 2003), is an even more intriguing context in Turkey. First, it is not only stigmatized but also banned in public buildings in this secular country whose population is mostly Muslim. In a middle-class, urban, secular social milieu in Turkey, adopting the veil is a choice that runs against the grain of consumer socialization. Second, Turkey, with its new designs of veiling and fashion marketers, influences veiling in neighboring countries as well as the Muslim diasporas in Europe. Third, the meanings and forms of veiling have changed tremendously in recent Turkish history. Many rural and elderly women have always covered their heads with a başörtüsü, a small scarf tied casually. However, in the early 1980s, a new, stylistically unprecedented form of covering appeared in big cities: a large head scarf that fully covered the hair, neck, and the shoulders and a long, loose-fitting overcoat (fig. 1).

Following colloquial Turkish, this new covering is referred to as tesettür, and those who are covered in that manner as tesettürlü, distinguishing it from the casual and traditional başörtüsü. This vigilant covering was initially adopted primarily by young, urban, and educated middleclass women who were formerly uncovered and whose mothers usually were uncovered. For the secular public, tesettür symbolized the increasing Islamist threat against the secular regime and, hence, unlike başörtüsü, it came to be politically stigmatized. The state passed a law banning the wearing of this new head cover in state offices, schools, and universities. Despite or due to the ban, tesettür spread, and its uniform look fragmented into a plurality of styles by the late 1990s. The overcoat yielded to fashionable tesettür clothes (fig. 2), and a lucrative tesettür fashion market developed. We wondered why and how a young, urban, and

\section{FIGURE 1}

1980s TESETTÜR: LARGE HEAD SCARF AND LONG, LOOSE OVERCOAT

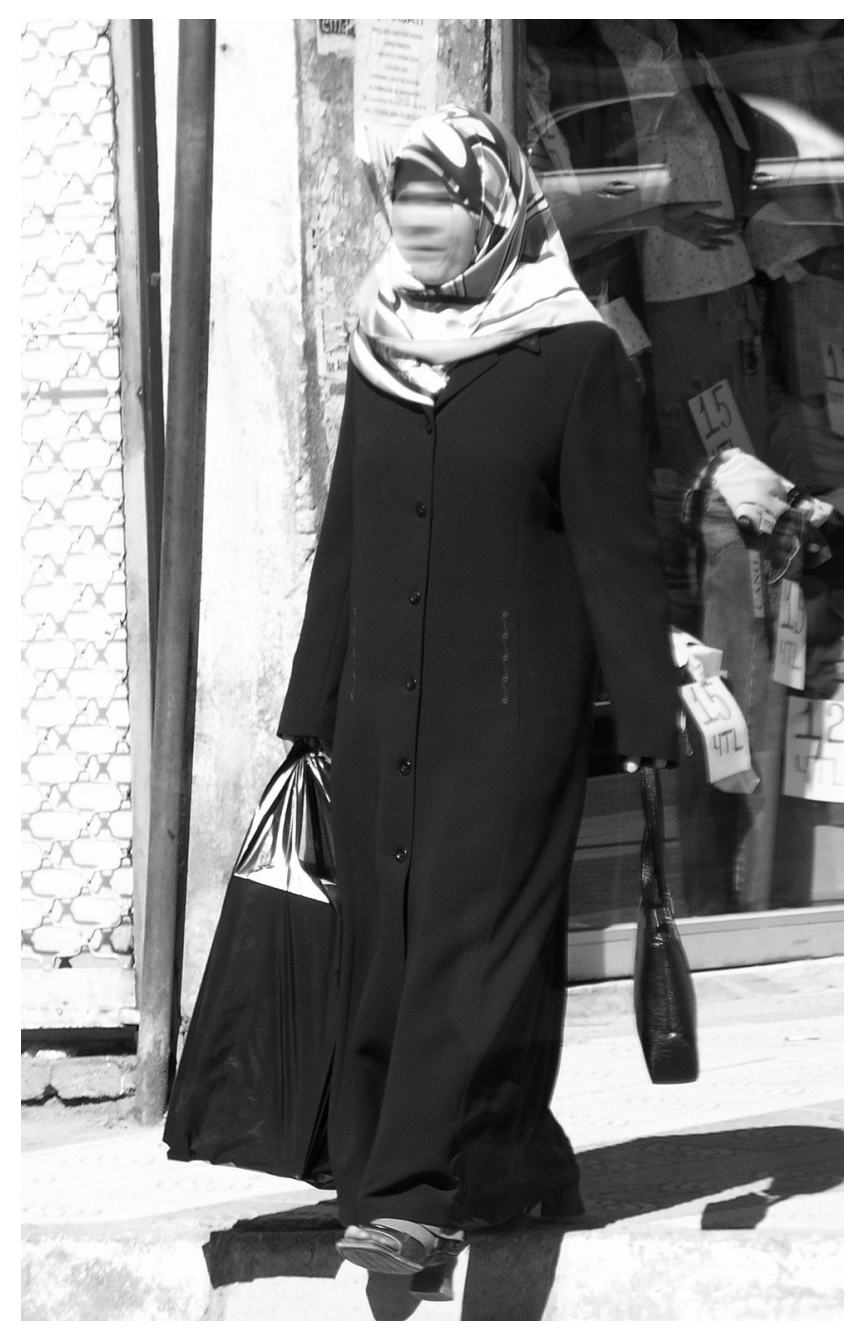

NOTE.-Color version available as an online enhancement.

educated middle-class woman would decide to cover, by her own volition, despite stigmatization and socialization. Equally intriguing was why and how tesettür styles changed so much and became more fashionable, popular, and ordinary. These dynamic and puzzling phenomena ignited our research.

We traced the changes in veiling in Turkey historically and mapped out the relationships that contributed to this seemingly undesirable practice becoming an attractive consumption choice, as well as the transformation in its status from a stigmatized practice to a fashionable and more ordinary consumption choice. The processes we uncover contribute to both the understanding of stigma as it pertains to consumption and the debates regarding the resurgence of Islamic veiling. 
FIGURE 2

CONTEMPORARY MIDDLE-/UPPER-CLASS TESETTÜR STYLES

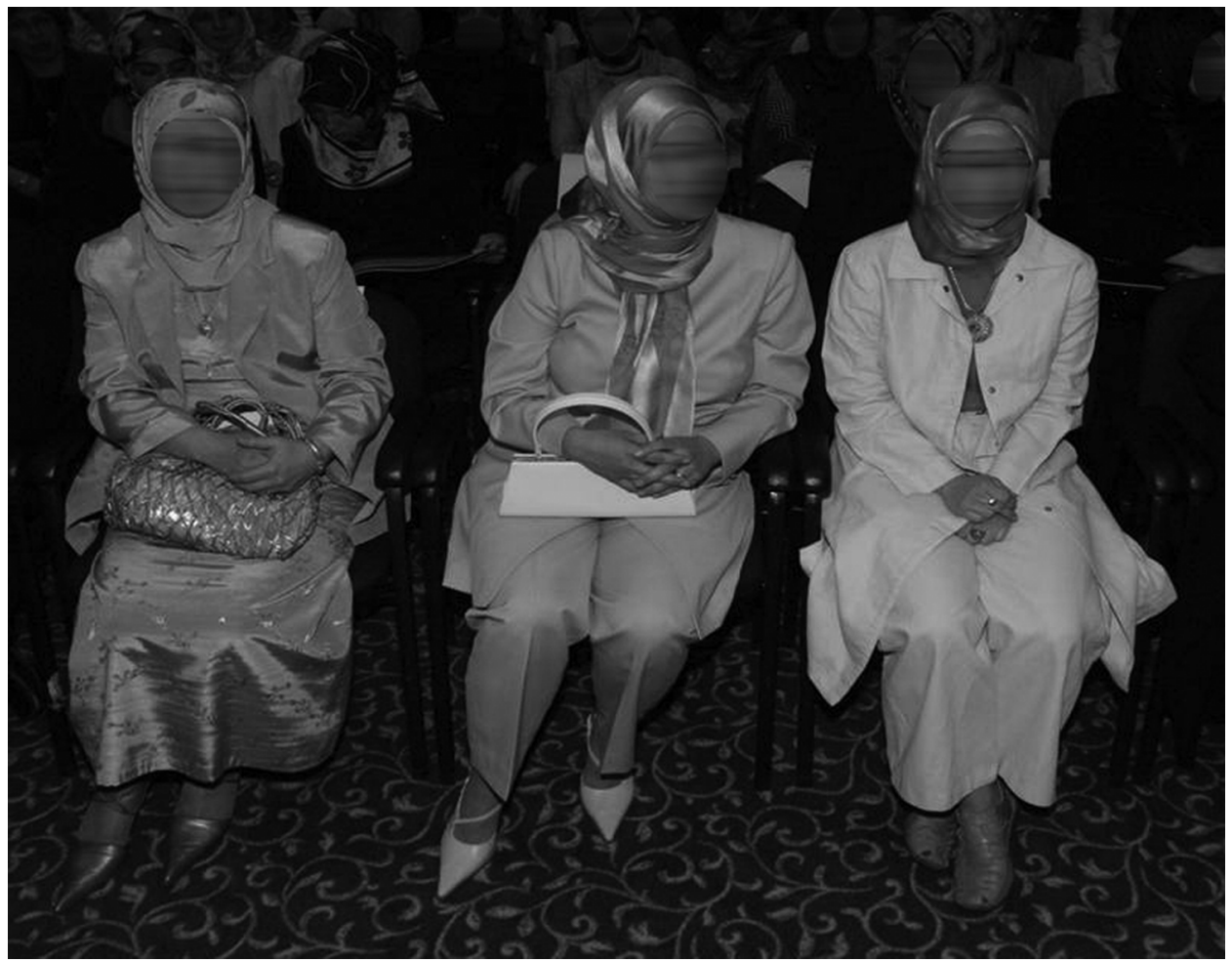

NOTE.-Color version available as an online enhancement.

\section{STIGMA AND CONSUMPTION}

Since the publication of Goffman's (1963) seminal work, research on the nature, sources, and consequences of stigma has grown rapidly (for reviews, see Dovidio, Major, and Crocker [2000] and Link and Phelan [2001]). Goffman defined stigma as "an attribute that is deeply discrediting" and argued that stigma reduces the bearer "from a whole and usual person to a tainted, discounted one" $(1963,3)$. According to Goffman, stigma is constructed by society on the basis of what constitutes "difference" or "deviance" from the normal and applied through social rules and sanctions. Although he emphasized the social construction of stigma and its relational and contextual nature, his conceptualization of stigma as a "discredited attribute" led to an undue focus on individualized analyses in which stigma came to be seen as something possessed by the person rather than as a designation by others (Link and Phelan 2001). Accordingly, much of the earlier research focused on identifying various sources of stigma and assessing its negative impact on the lives of the stigmatized individuals.

Recent approaches emphasize that stigma is not a fixed or discrete attribute located in the individual but a socially constructed and dynamic evaluation (Dovidio et al. 2000), and discuss stigmatization as a social process implicated within relations of power (Link and Phelan 2001; Parker and Aggleton 2003). Stigmatization involves distinguishing, labeling, and stereotyping certain differences and thus a separation between "us" and "them" (Devine, Plant, and Harrison 1999). However, such a separation is contingent upon access to power. While in theory any difference can be stigmatized, what ultimately gets labeled as stigma reflects the interests of the dominant groups. Hence, stigmatization becomes "inherently linked to the production and reproduction of structural inequalities" (Parker and Aggleton 2003, 19).

If so, a stigmatized practice becoming an attractive choice for some, and later transforming into a fashionable and ordinary consumption choice for many, suggests power struggles among different groups. As not all stigmatized practices go through such change, we believe that understanding how and why particular practices do so can shed further light onto the role of consumption in challenging, negotiating, and reconfiguring power relations and social hierarchies. Studies demonstrate that the marketplace operates as a domain where power is both reproduced and contested (Arnould and Thompson 2005; Askegaard, Arnould, and Kjeldgaard 2005; Belk, Ger, and Askegaard 2003; Fischer, Otnes, and Tuncay 2007; Holt 1997, 1998; Kates 2002; Kozinets 2002; Thompson 2004, 2005; Üstüner and Holt 2007). In- 
dividuals can and do use consumption practices to challenge what is regarded to be normal. Yet, consumers also engage in consumption practices that reflect their tacit acceptance of cultural norms and contribute to the reproduction of existing relations of power. The change in the status of a stigmatized practice illustrates a particular form of struggle over difference through which a new consumption norm gets constructed.

However, despite its relevance and significance, interest on stigma remains scant among consumer researchers. Only a few studies address stigma directly (Adkins and Ozanne 2005; Argo and Main 2008; Henry and Caldwell 2006), and a few others address it indirectly (Hill and Stamey 1990; Kates 2002; Kozinets 2001; Muñiz and Schau 2005; Schouten 1991; Tepper 1994). These studies focus on the negative effects of stigmatization and examine various stigma management strategies used by consumers. They find that stigmatization may constrain consumers' choices in the marketplace, inhibit their responsiveness to promotional offers, and lead to feelings of helplessness. Consumers employ different strategies to cope with the negative consequences of being stigmatized: some passively accept stigma and suffer from low self-esteem, shame, or poor consumption performance; others fight against stigma by challenging or rejecting the constraints it brings.

While existing research provides important insights into stigma management, the focus on the individual overlooks the dynamics and ramifications of stigmatization or destigmatization as social processes. The emphasis on individual outcomes unintentionally results in treating stigma as a relatively static construct: whether the consumer passively accepts or actively fights against the stigma, the status of the practice remains the same. We advance this body of work by shifting the focus from coping strategies to the processes through which a stigmatized practice becomes an attractive choice and its stigma status changes. We also contribute to the scholarship in psychology and sociology by empirically explicating the relationship between power, stigma, and social ordering.

\section{STIGMA AND THE ISLAMIC VEIL}

The practice of veiling exists in many belief systems, yet, today, it almost exclusively denotes Islam, and more often, "the problems of Islam" (Watson 1994, 153). In the post9/11 era, the veil appears even more troublesome and circulates as one of the most visible markers of the so-called Islamist threat to the Western liberal secular order. Whether it is when a Georgia judge jails a Muslim woman for wearing her head scarf to court (Walker 2008) or the French government bans female students from wearing the veil at school (Bowen 2006), the assumption seems to be that covered women are the "unruly elements" (Sheth 2006) of a Western secular society who need to be concealed, controlled, and even punished. As Göle (2003) argues, as a bodily sign and practice through which difference and exclusion are carried out, the veil typifies what Goffman originally discussed as stigma.
The history of stigmatization of the Islamic veiling dates back to the colonial encounters between the East and the West. Orientalist readings cast Muslim women as oppressed and backward subjects who cover themselves because they are either brainwashed or forced to do so (Hoodfar 1993; Said 1978). In either case, veiling indicates compliance to a patriarchal authority and signifies Muslim women's subordination and lack of agency (Afshar 1998; Hoodfar 1993; Mernissi 1991). As an oppressive practice, veiling also illustrates the inferiority of the status of the Orient in relation to the Occident (Ahmed 1992; Said 1978). Accordingly, abandoning the veil becomes a necessary condition not only for the emancipation of individual women but also for the progress of Islamic societies. Indeed, in many Muslim countries, unveiling constituted a key element of the "modernization" projects undertaken by the local elites in the early twentieth century (Hoodfar 1993).

Women's head cover played a crucial role in Turkish modernization as well. In the Ottoman Empire, which was ruled by the Islamic law, veiling used to be both a religious and legal obligation for all Muslim women. In the Turkish Republic, which constituted itself as a secular, Western-looking nation state in 1923, veiling came to be perceived as a sign of the discarded Islamic Ottoman past (Delaney 1994; Saktanber 1994; Secor 2002). Although women were not legally forced to remove their veils, unveiling was encouraged and indicated one's commitment to the republican ideology and its secular regime. As Yeğenoğlu explains, "the unveiling of women became a convenient instrument for signifying many issues at once, i.e. the construction of modern Turkish identity, the civilization and modernization of Turkey and the limitation of Islam to matters of belief and worship" (1998, 132). While unveiled women enjoyed the benefits of a modern female identity, those who continued to wear the Islamic garb found themselves donning a "traditional," "rural," and "backward" identity.

In Turkey, until the 1970s, veiling was mostly associated with and practiced by the peasants, the poor, and the elderly. However, in the early 1980s, young, urban, middle-class women began to cover themselves in a new style. With the rise of political Islam, the trend toward adopting Islamic clothing became apparent not only in Turkey but in many countries, including places where this practice had previously been almost nonexistent, such as Bangladesh (Rozario 2006) and Java (Brenner 1996). This increasing interest in veiling, sometimes referred to as the reveiling movement (Zuhur 1992), did not simply indicate a heightened religious sensitivity, but more so, a collective expression of the commitment to Islamism as a new global social movement (Brenner 1996; El Guindi 1999; Göle 2003). As veiling became politicized, it also became restigmatized.

Islam in Turkey is, of course, embedded in and informed by global Islam. Islamism has been one of the key developments shaping the world in recent decades (Bayat 2005; Wiktorowicz 2004). Islamist movements parallel the logic of new social movements and seek to create "networks of shared meaning" (Melucci 1996) based on alternative ways of living. 
These networks help build communities, which provide spiritual and material support to their members. Islamist movements have also been providing new opportunities for women. For those affiliated with the movement, access to education and work, and participation in politics, have been easier within their network. However, Islamism also inadvertently restigmatized the veil. As Said (1993) argues, since the 1980s, fundamentalism and terrorism have become interlinked; Islam has come to be understood as fundamentalism and thus often as terrorism. The events of $9 / 11$ reinforced this perception, and Muslims around the world were burdened with the labels of terrorism and evilness (Afshar 2008). Being a visible marker of a Muslim identity, the veil has become firmly linked to Islamist fundamentalism.

As we elaborate later, along with the influence of global Islamism, the new style of veiling, tesettür, became increasingly visible in urban Turkey. For the secular public, this reveiling represented the "dark side of modernity" (Göle 1996) or the "reverse" of it (İlyasoğlu 1994), and tesettürlü women the "other" (Saktanber 1994) of the pro-Western, progressive, and "modern" Turkish women. Thus, tesettür became the object of restigmatization. Marking tesettür as the symbol of the Islamist threat against the secular regime and "modern" lifestyles, the state banned the wearing of it in schools, universities, and state offices.

However, despite the stigmatization and the discrimination they face, women, in Turkey and elsewhere, have continued to voluntarily adopt the new veil and have done so for a variety of reasons and in a variety of ways (AbuLughod 1986; Ahmed 1992; Mahmood 2001; Saktanber 2002). Furthermore, there is now a sizable transnational veiling fashion industry, and covering is increasingly embedded in the logic of consumerism (Balasescu 2003; Gökarıksel and Secor 2009; Sandıkcı and Ger 2007). In countries such as Turkey, Egypt, and Malaysia, where veiling used to be a sign of backwardness, traditionalism, and, more recently, resistance to the West, fashionably covered women now represent a new position (Abaza 2007; White 2002). While in many Western countries restigmatization of veiling has been intensifying, in some other contexts, the new veil is now more of a fashionable consumption choice. By examining how the transformation of veiling from stigma to fashion has happened and teasing out the personal and societal ramifications of the change, our study also provides new insights for the literature on veiling, which has tended to focus more on the issues of agency, resistance/oppression, and gender relations.

\section{METHODOLOGY}

We conducted ethnography over 4 years at multiple sites, using multiple methods. We set out to study a specific population: urban, educated, middle-/upper-middle-class covered women who covered out of choice rather than habit or force. We began by holding extended discussions with the covered wife of a colleague. She became one of our key informants and introduced us to her friends. Through snowballing, we were able to meet new informants. As we con- ducted our initial interviews, we realized the immense heterogeneity among covered women. How women interpreted and practiced covering seemed to vary by demographics, years of covering, life stage, political views, and cultural and financial resources. Thus, the emergent sampling frame entailed groups such as students, housewives, feminists, and professionals who varied in age, income, years they had been covered, political orientations, and life stages, all in Istanbul and Ankara.

Housewives and career women were relatively easier to access and more willing to talk with us. However, interviewing university students was a real challenge. Because the ban against religious head covering at universities is a contentious issue, when we tried to contact covered students on campus, we were usually refused or evaded. Eventually, we hired a recent sociology graduate who was willing to conduct interviews. She interviewed 10 students and became our second key informant herself. Furthermore, six trained graduate students interviewed women within their own social milieus.

We and our associates interviewed 42 covered women (table 1). Six professional women and 10 students constituted the friends or friends of friends of our two key informants, respectively, and five other informants were members of the same woman's organization. Thus, we were able to explore the relationships in these three social networks as well. Openended interviews were conducted at the informants' homes, offices, or cafes, depending on their preferences. The interviews lasted from 1.5 to 4 hours. When we conducted interviews at homes, we also observed general consumption preferences and styles of home decoration. Moreover, we were able to inquire about our informants' favorite clothes and scarves, some of which we were able to see and photograph. We held conversations regarding clothing, fashion, shopping, reference groups, likes and dislikes about clothes and media, brand preferences, and likes and dislikes in various consumption domains. We also inquired about their stories of covering at the time they covered.

We soon realized that four areas needed further investigation: the opinions of uncovered women, the details of head scarf selection and use, the marketing side, and international connections. We noticed that the gaze and judgments of uncovered women, friends as well as strangers, were crucial for our informants' practices and feelings. Hence, we interviewed 10 uncovered women-five who were strictly against covering and five who were more lenient. We inquired about their own clothing practices as well as their views on covering and covering styles. Second, since the scarf emerged as the most significant aspect of covering, we conducted short interviews with six more covered women. We chatted about diverse styles of tying the scarf; preferences for different fabrics, designs, and brands; and shopping for scarves. Third, we interviewed the owners of a mid-size tesettür fashion company and the salesclerks of nine tesettür stores in Ankara. The former informed us about design, advertising, and retailing; the latter about the roles tesettür stores and salespeople play in assisting the selection of clothes and head scarves. 
TABLE 1

PROFILE OF COVERED INFORMANTS

\begin{tabular}{|c|c|c|c|c|c|}
\hline Pseudonym & Age & Education & Marital status & Occupation & SES \\
\hline Damla & Mid-40s & MS & Married & Engineer & Middle \\
\hline Mine & Early 30s & University & Married & Housewife & Upper middle \\
\hline Fatma & 25 & University & Single & PR manager & Middle \\
\hline Nil & 35 & University & Single & Teacher & Middle \\
\hline Meltem & $20 s$ & High school & Married & Housewife & Middle \\
\hline Ayşe & Late 30s & University & Married & Housewife & Upper middle \\
\hline Alev & Mid-40s & University & Married & Teacher & Middle \\
\hline Dilek & Late 20s & University & Single & Teacher & Upper middle \\
\hline Aslı & 35 & University & Married & OFW & Middle \\
\hline Sema & 36 & High school & Married & OFW & Middle \\
\hline Serap & Early 40s & $\mathrm{PhD}$ & Married & OFW & Middle \\
\hline Merve & 37 & University & Married & OFW & Middle \\
\hline Süheyla & Early 40s & MS & Married & OFW & Middle \\
\hline Seda & 58 & High school & Married & Own business & Upper middle \\
\hline Hatice & 54 & University & Married & Housewife & Upper middle \\
\hline Zübeyde & 42 & High school & Married & Housewife & Upper middle \\
\hline Zahide & 25 & University & Single & Student & Middle \\
\hline Sibel & 21 & University & Single & Student & Lower middle \\
\hline Nuran & 22 & University & Single & Student & Lower middle \\
\hline Bahar & 24 & University & Single & Teacher & Middle \\
\hline Elif & 19 & University & Single & Student & Middle \\
\hline Şükriye & 20 & University & Single & Student & Middle \\
\hline Arzu & 23 & University & Single & Clerk & Middle \\
\hline Nilgün & 26 & University & Single & Teacher & Lower middle \\
\hline Hande & 25 & University & Single & Teacher & Middle \\
\hline Selin & 24 & University & Single & Teacher & Upper middle \\
\hline Berna & 30 & MD & Single & Doctor & Upper middle \\
\hline Saadet & Late 20s & University & Single & MOE & Middle \\
\hline Aynur & 19 & University & Single & Student & Middle \\
\hline Bilge & 19 & University & Single & Student & Middle \\
\hline Nur & 32 & University & Married & MOE & Middle \\
\hline Bilsen & 30 & University & Married & MOE & Upper middle \\
\hline Sevgi & 33 & University & Married & MOE & Lower middle \\
\hline Gülçin & 51 & University & Married & MOE & Middle \\
\hline Ayşen & $30 s$ & University & Married & MOE & Middle \\
\hline Nükhet & 20 & University & Single & Student & Lower middle \\
\hline Hadise & 23 & University & Single & Student & Upper middle \\
\hline Gülden & 20 & University & Single & Student & Lower middle \\
\hline Yeşim & 21 & University & Single & Student & Middle \\
\hline Zeynep & Mid-20s & University & Single & Journalist & Middle \\
\hline Ebru & Mid-20s & University & Married & Journalist & Middle \\
\hline Gül & Mid-20s & University & Single & Journalist & Middle \\
\hline
\end{tabular}

NOTE.-SES = socioeconomic status; it reflects our subjective estimate. OFW = organization for women, an NGO; its members identify themselves as feminists. MOE = municipality-owned enterprise. Note that the Ankara municipality has been governed by the (Islamist) JDP since 1999.

Finally, we explored institutional links in Germany, where a substantial Turkish immigrant population resides. We spent 1 week in Kreuzberg, Berlin, the biggest Turkish neighborhood in Europe, and interviewed two German officials and four Turkish businessmen.

We also carried on ethnographic observation. In addition to the homes and offices of our informants, we observed covered women at streets, stores, shopping malls, restaurants, hotels, Islamist political party headquarters, fashion shows, weddings, women's clubs, and religious meetings, where we were able to observe not only the clothes but also the group dynamics. For example, at several tesettür fashion shows, we observed women coming in, gathering, and watching the models and eavesdropped on their comments about the show. At tesettür clothing stores, we observed women as they tried on clothes and scarves and talked to their companions and salesclerks about the items they considered buying. We spent a weekend at a five-star summer resort catering mainly to Islamist clientele. We interviewed the public relations manager and a clerk. We observed women sunbathing and swimming at the all-female swimming pool. We watched tesettürlü women playing tennis or strolling with their friends or families during the day and belly dancing to the songs of Shakira, Ricky Martin, and local singers at night in the all-female disco. We each kept independent field notes at each site and then compared them.

Moreover, we relied on visual and textual materials dating back to the 1980s. Our archive included images that circulate in the media as well as advertisements, brochures, and catalogs that target covered women. It also included news sto- 
ries, debates, commentaries, and opinion pieces on covering that appeared in print and broadcast media as well as on the Internet. We read numerous Islamic romance novels and magazines that were popular among our informants. We took photos ourselves whenever it was appropriate and ethical to do so.

The analyses and fieldwork overlapped to some extent as we attempted to evaluate and refute emerging interpretations via purposive sampling. The transcripts of a total of 73 interviews, field notes, and textual and visual material were read several times, coded, and analyzed using constant comparative, narrative, and deconstructive analytical techniques. We analyzed the data by iterating back and forth between the parts and the whole of each text and between each text and the entire data set. After we identified an initial set of themes and features, we scrutinized the data in both piecemeal and holistic modes, related data from various sources to the literature, discovered a new set of themes and relationships, and then iterated on. We also compared data across different subgroups such as the feminists, students, younger and older informants, those who covered in the 1980 s versus the 1990s, and those new and not so new to covering. Each of us read the data and wrote notes on emergent themes, first on our own, and then we compared notes. As we interrogated each other's interpretations, we discovered new connections and angles. The disjunctures between actions and verbal reports and between the consumers' versus the salesclerks' reports helped us identify various tensions and paradoxes and figure out how covered women try to cope with them. We also conducted diachronic analysis in an attempt to expose various temporal dynamics we noticed in the informants' narratives. Diachronic analysis, while it led us to more iterations and a few re-interviews, was very valuable in providing us with some key insights.

We identify two limitations. The first pertains to the difficulty of being an insider in the context we studied. As two uncovered female researchers, we inevitably had difficulties in penetrating the religious orders and some institutional settings. Not being members of this new community, we had to rely on the accounts and texts of insiders. The second pertains to the context itself. To be able to generalize our findings, future research is needed to compare the processes we identified to those that exist in the context of other stigmatized practices in other countries.

\section{FINDINGS}

Below, we explicate the covering choices and practices in the context of the sociopolitical history of Turkey; as such, individual-level processes are embedded in macro processes. We discuss two sequential yet overlapping processes: choosing the deviant in the 1980 s and performing the deviant in late 1990s and early 2000s. First, we explicate how our informants adopted an emergent stigmatized practice, despite their socialization. We identify that their search for stability and comforting boundaries and their encounter with a new community stimulated their choice at a time of a growing neoliberal market and rising political power of Is- lam, following a period of political strife. Second, we explain how covered women have been performing tesettür, the new veiling, and how they have been relocating from uniform to diverse and fashionable outfits. We discover that the processes of personalization and aestheticization, contemporaneous with the emergence of a new Islamist middle class, routinized the new veiling. This new class owes its existence to the upward mobility and urbanization of the formerly rural, peripheral elites and small businesses who have been taking advantage of the "opportunity spaces"-market-oriented venues to spread ideas and practices (Yavuz 2004)_created by the neoliberal economic policies. It now forms a parallel structure that competes with urban secular elites, in consumption as well as in production.

\section{Choosing the Deviant: Emergence of Tesettür}

The sight of the new veiling of the 1980s by educated urban middle-class young women, who were anything but subdued, clashed with the urban imagination that associated covering with backward lives. Turkish modernization has been associated with Westernization (Keyman 2007). The Westernizing aspects of the Republican revolution entailed a shift from "Islamic" (i.e., backward, traditional, rural, Ottoman) to "secular" (i.e., civilized, modern, rationalist, urban, European) ways of life. Turkish secularism, modeled after French laicism, has been based on the division between the private sphere, to which religion belongs, and the public sphere, in which individuals should act devoid of religious affiliations (Davidson 1998). Secularism had been embraced mainly by the urban civil, military, and business elites who formed the "center," and religiosity by the rural elite and small businesses who formed the "periphery" (Mardin 1973). Over the years, covering became a key marker of the rural-urban division and class identities.

Tesettürlü women contradicted the prevailing meaning of covering in Turkey. They were visibly religious and yet not rural, poor, or elderly. They had chosen to engage in a practice that was associated with the lower classes. However, the way they covered themselves was completely different from the existing styles of covering. Tesettür was a novel, unique, and, for the secular public and state, politically driven practice. Indeed, as Islam ascended and tesettür became more visible, the polarization between seculars and Islamists intensified. The 1980s saw frequent clashes between the police and tesettürlü women who protested for their right of education. While tesettürlü students protested the ban on covering, secular women, in miniskirts and Atatürk pins, rallied to Atatürk's mausoleum.

The hard-line seculars among our uncovered informants maintain that they have been irritated by the sight of tesettürlü women and adamant to "educate" the latter to "open" their minds and heads. Our covered informants, in turn, state that they felt being stigmatized. Most of them have had personal experiences of being picked on, scolded, or ridiculed because of their scarves and the clothes they wear. The knee-jerk reaction against tesettür was so strong that some were stigmatized even by family members. Gulcin 
explains: "My sister-in-law is a history teacher at the high school. When we first met after I covered, I don't know, maybe she was so surprised, her first reaction, before even saying hello, was to try to pull my head scarf down. I mean how can such a cultured person be so intolerant? . . . Covering is my own choice. I used to be uncovered, wear swimsuits . . . miniskirts. But if I have chosen this, you have to think about its reasons. . . . Obviously, I have chosen this because it makes me happy."

But, how did the sisters of uncovered women, socialized in the same milieu, willingly shift to stigmatized tesettür, which they hope will make them happy? Our informants smile and provide lengthy narratives to explain their "voyage" to veiling, be it in their 20s or 40s. Consider Serap, a prominent activist in a religious women's organization. Her "adventure" began during her high school years. She recalls that she was faithful but never regarded herself as the "covering type." One day she saw a teacher forcing another student to take her head scarf off. Serap felt very angry, protested, and challenged the teacher. This was the first time, she says, she thought about covering. The following summer, she read numerous books on Islam and on European Christians converting to Islam, in addition to her usual "world literature": "I realized that the converts follow all the rules very sensitively. They cover but we don't? I had to make a decision: either I would give up being faithful or I would take my faith seriously and practice it properly. I decided logically." Serap's decision to cover entailed resistance to a teacher, mimesis of converts, and a year-long process of reading and thinking. As other informants' experiences also indicate, religious books have been important for familiarizing women with Islam. In the 1980s, along with the rise of Islamist movements, educational and theological publications on Islam began to proliferate. These included works of Turkish writers as well as translations. The common thread was their emphasis on a new interpretation of Islam and a vision of life shaped by the Islamic principles (Kentel 2004).

Adopting tesettür is part and parcel of embracing such a change in the vision of life. Whatever triggered their eventual move to tesettür, our informants regard covering as a "life choice"-an identity project. For them, if a Muslim woman is to take her faith seriously, wearing a scarf and nonrevealing clothes is a duty. Noting the time and deliberation they put into their decision to become a "true" Muslim, informants underline that covering was a well-thoughtthrough choice, indicated by Serap's accent on logical thinking. The work that went into that choice had been intense, since covering meant going against the norms of their former milieu, which Serap and others abandoned in their search for comfort.

Searching for Comforting Stability and Boundaries. Ebru, a documentary director working for an Islamist television channel, started her story of covering with her family's move from a small Anatolian town to Istanbul in the late 1970s. The reason for the move was the right-wing/leftwing strife. Because university campuses were sites of vi- olent clashes, her parents wanted to be close to her brothers, who were attending a university in Istanbul. She recalls that, after they moved, discussions of communism, capitalism, fascism, and nationalism, as well as concerns for safety, became commonplace at home. She thinks that her early encounter with politics made her ask existential questions at a young age. She explains:

I covered first in high school, then uncovered to be able to attend the university, then covered again upon graduation. These decisions to cover and uncover were all my own. But when I was uncovered, my conscience was not at ease: I felt I did not belong there. I had been reading many different ideologies. At times I felt close to socialism. But I felt each ideology had something missing. But religion, since it is divine, is complete. I grew up questioning things; we were the political youth of the early 1980s. I also questioned why I was not living a more faithful life. . . . At the university, I met my current husband, who was a student too and a Marxist. Like me, he had begun to develop a desire for a more Islamic life. He and I, we motivated each other.

Ebru's choice evolved in the midst of concerns over family safety and interrogations of diverse ideologies. She pondered over the teachings of various religious organizations she encountered at school and the university. Attempting to propagate Islam among the youth, such organizations have been emphasizing veiling. As her identity project of living a faithful life crystallized, she felt that she no longer belonged there in the social milieu of the uncovered, or "open," moderns.

Other informants' trajectories also reflect the unsettling repercussions of the left-wing/right-wing strife. The 1970s saw violent uprisings, attacks, and clashes. Alleging to stop the strife, the military took over in 1980 and abolished the parliament. The military leaders, despite their seemingly strong adherence to secularism-expressed, for example, by the 1981 law banning the religious head cover in public buildings - regarded Islam as a safeguard against leftist ideologies. They took a number of actions to solidify the place of religion in public life: religious courses were made compulsory in all schools, religion studies schools were opened, and many new mosques were built. The right-wing party, which came to power in 1983 after the military stepped down, maintained a similar approach. Accordingly, the number of mosques rose $47 \%$ between 1981 and 1988 (Vertigans 2003). In addition, the Turkish state's more tolerant attitude toward Islam was in line with the U.S. strategy of fighting communism with Islam in the Middle East and Asia. This global support was more than solely ideological: significant financial assistance was provided by the United States and Saudi Arabia. The funds were used to set up new religion education facilities, support newly active religious orders, finance Islamist firms, and offer scholarships to university students (Demir, Acar, and Toprak 2004). The tension between leftist and rightist ideologies and the cold war politics of the era contributed to the development of political Islam in Turkey, as elsewhere (Gülalp 1999; Toprak 1984). 
Like Ebru, Seda's move also seems to have been shaped by such tension. Seda recalls beginning to be attracted to religion during the worrisome late 1970s. She tells of her visit to eastern Europe in the early 1980s out of curiosity for what communism had to offer and her disappointment at what she saw. Later, in 1986, she went for the Hajj, and, on her way back home, she stepped down from the plane in tesettür. She remembers her fear that her family would disapprove. While no one said anything at first, her husband, sons, and friends opposed her decision and asked her to reconsider. She beams as she says that eventually "they accepted me as I was and respected my choice." Given Ebru's and Seda's allusions to the distressed, uncertain, and unsafe times they had lived in, it is not surprising that they yearned for some stability - both political and spiritual-in their lives. Perhaps disillusioned by both socialism and nationalism and attempting to escape the left/right strife, the informants embraced the intensively promoted Islam, hoping that it would provide comforting solutions to their anxieties and a sense of control over their lives.

In addition to such macro anxieties, a more daily set of anxieties also had a bearing on the decision to cover. Informants' stories frequently refer to the anxieties of an open (uncovered) way of life: the conundrums of what to wear. Serap explains: "If you are uncovered, your boundaries are blurry, confusing, ambiguous. . . . But when you cover, tesettür clarifies your boundaries. That's easier, simpler, more comfortable." As her words reflect, there is a common belief among our informants that an open lifestyle is characterized by too much freedom and a resultant dilemma about how to present the self in everyday life (Goffman 1959). In contrast, our informants find some boundaries, such as those offered by tesettür, to be "comforting." Tesettür responds to the usual "What should I wear?" question, much like the anxiety-reducing black dress (Clarke and Miller 2002). Attempting to escape daily worries, our informants embrace the boundaries set by tesettür, which, they argue, free them from the obsession with appearance, the work of dressing, and the chores of shopping.

The notions of femininity are clearly associated with this micro anxiety of dress. Serap added that she wanted to wear clothes that were not "sexually provocative" and that enabled her "to preserve the boundaries of friendship with men." Others also feel that being covered makes relations with men easier by announcing their "lack of availability" and protecting them from being regarded as sex objects. Bahar, a sociology graduate who works as an instructor at a private school, remembers how gratified she felt after choosing to submit to the boundaries of tesettür: "I used to be a girl in shorts, riding a bike. . . . But then, at high school, I began to think about certain things [she began to affiliate with a religious order]. . . . I was deeply affected by some books I read. Better live in accordance with your faith. Until then, men gave me looks, mouths drooling. When I wore the long overcoat for the very first time, I felt protected, very secure. I felt respected. I liked it a lot. I remember smiling."
Among the books Bahar read are Islamic novels. Islamic fiction-novels, poems, and plays-has been spreading in Turkey and elsewhere, along with the rise of the Islamist movements (Malti-Douglas 2001). In Turkey, the novel form became especially popular. These books, often referred to as salvation novels (Çayır 2007), targeted mainly women and, through their highly didactic narratives, urged their readers to adopt the "true" Islamic lifestyle. Constructed in the genre of romance (Radway 1991), these books typically begin with an unhappy character who is ignorant about or hostile toward Islam. She or he lives a modern life, characterized by superficial relationships, sexual promiscuity, alcohol abuse, and other sinful practices. At the end of the story, the character, who falls in love with a Muslim male or female, finds the "right way" and chooses to become a "true" Muslim. For female characters, such enlightenment always involves adoption of tesettür, which not only brings happiness but also becomes symbolically linked to romantic and spiritual love.

Similar to the novel heroines, Bahar and others mention how comfortable, happy, and empowered they felt after adopting tesettür. Even though they might not have necessarily found love, they recall the ease they felt in mingling in the public life without the burden of the male gaze. Serap explains: "After I covered I became very comfortable. Men exclude you from the category of women who can be stared at and bothered. I was never harassed. Even though I was out at night by myself, I could come and go as I please. You erase the thoughts of trying to be beautiful for a man. You gain a personal power . . . develop your character."

Serap and others insist that they chose tesettür because covering enables them to assert themselves as persons rather than sexual beings. Whether this is a justification or a motivation for covering is irrelevant, as justification is an integral part of action, not always separable from its motivation (Campbell 1990). In any case, our informants raise the "problem of indecency," which they link to the modern society. A prevalent topic in the conversations at the seaside resort and the women's club was the "unfortunate indecency" rampant in the media and the films. Such indecency typically refers to too-revealing clothes, such as low-cut tops and tiny miniskirts, and "too-free" urban lifestyles, for example, the wild nightlife. In contrast, tesettür enables our informants to express their modern identity while distancing themselves from such "immodesty." It enables them to reconcile a tension posed by being modern-something that they deem desirable because it is seen to be progressive yet undesirable because it is also seen to be morally threatening. And, the more they experience the comfort and empowerment of tesettür, the more they settle into their ways.

In their quest for removing various anxieties and moral threats from their lives, our informants willingly submit to "certain boundaries." While they embrace these boundaries, they suffer from a new set of restrictions posed by the changes in their new life. As Ebru explains, social milieu, leisure pursuits, and places frequented all change: "For two 
years after I covered, I had to carry on alone. I could not meet up with friends. After you cover, the places you can go to are limited. You bring boundaries to yourself: you don't go to the seaside, resorts, movies, or restaurants and bars that serve drinks. . . . Everything changes. Initially you go through a period of purification. It was difficult but I felt happy." After such initial withdrawal from life as they knew it, our informants elaborated that they eventually made friends with more religiously oriented people and became part of a new community. While they may not be thrilled with all of these changes and, for example, still miss the beach and "the sun caressing my body, the wind blowing my hair," they insist that they are content with these comforting restrictions and that they willingly accept them for the sake of a more virtuous way of life. This willing submission seems to provide a sense of pride, self-respect, and higher moral ground.

The informants' accounts of their decision to cover and their acceptance of the limits it brings are consistent with Foucault's notion of self-restraining subjects. Foucault's modern subjects choose to restrain themselves through practices, such as dieting, physical exercise, and other forms of self-control, in order to pursue what they believe to be happiness, purity, and wisdom (Foucault 1984, 1986). The relationship one ought to have with oneself, which Foucault calls ethics, determines how the individual is supposed to constitute herself as a moral subject of her own actions. In the case of the covered urban women in Turkey, the selfdisciplining female willingly submits to the limits of tesettür in her quest for comfort, stability, empowerment, and spirituality, and in doing so, claims to free herself from the enslaving male gaze. Perhaps the stiffness, the seriousness, and the stern looks that we observed on the faces and in the gestures of most tesettürlü women are a reflection of such self-restraint. If, for many, tesettür provides a solution to the macro and micro anxieties of the modern world and, at the same time, becomes a means through which they constitute and maintain themselves as moral subjects, stiffness may be a price to pay. During their "voyage" to veiling and away from their former social milieu, they find a new community.

Finding a New Community. While accounting for their decision to adopt tesettür, most informants talked in the "we" form, and some explicated the more communal and political aspects of the spread of tesettür. They alluded to the reading sessions held regularly and frequently at homes or meeting places. Correspondingly, our uncovered informants as well as the media expounded on how religious organizations have vigorously been recruiting and financially supporting university students. Our now-covered informants went through a process of discovery, learning, negotiation, and legitimizing while moving toward the choice of covering and the connected decision of living a properly faithful life. That decision was shaped by the Koran, the hadits - the practices recommended by the prophet Mohammed-and Islamic literature, as well as their emergent social circle. Serap was one of the more open informants who explicitly talked about religious-order linkages in the decision to cover. Her account is based on her own experience as well as those of the larger community of the covered women she socializes with as part of her work for a woman's organization: "You know, religious orders and schools flourished in the 1980s. . . . Tesettür started in religious communities. Girls began to go to Koran classes [outside the school] and wear tesettür. . . . Then many others, not allied with any religious order at all, began to cover just because they were angry at the teachers. . . . As the teachers . . . forced the girls to take their head scarves off, more began to cover. To protest, to react." Media accounts corroborate Serap. Local and international Islamic organizations used the language of human rights and freedoms to inspire a turn to religion (Secor 2002). As the images of tesettürlü women being denied access to schools and forced to take their scarves off circulated, tesettür turned into a symbol of freedom and became attractive for some.

By adopting tesettür, women became part of this new community, if not an order. New spaces such as the allfemale neighborhood clubs run by the Islamist municipalities or other organizations, where they socialize and engage in various leisure activities such as exercising, singing, or learning how to use a computer, provide ample opportunities for interaction. As they learned from each other and from the books they read together, they braced and strengthened this community - their newly emerging safe haven-despite or perhaps due to the fact that their new affiliations clashed with their old ones. The new community helped them endure various criticisms such as "You are wasting your youth" from uncovered friends and family. The uniform look of the 1980s tesettür provided a feeling of camaraderie. Among the Turkish immigrants abroad, for example, in Germany, such camaraderie was even more important. As social ties between immigrants and their relatives in Turkey are strong, and as some of the most powerful Islamist organizations operate out of Germany and elsewhere, Islamic collectivities stretched internationally.

In the 1980s, "everybody" wore the long, loose overcoat and the large head scarf, which seemed to materialize the stiffness, the self-restraint mentioned above. We wondered where this new look came from. Some informants discussed how their mothers or tailors sewed it for them, based on their specifications. The urban covered Turkish women seem to have invented the tesettür overcoat in the 1980s by making the existing models of winter coats looser, longer, and, for the summer, lighter. This uniform outfit followed the uniformity of the discourse about how tesettür should be practiced, as Bahar contends: "When I first covered, I had many principles. .. . I applied the norms much stricter. There was a view that if you were covered you should dress in a particular way. . . . There were no alternative models. My first overcoat was so big, I used to get lost inside it." Despite the fact that she had her clothes sewn and could therefore choose any model she wished, she went along with what she saw others in her new community wearing. The new look served to make a statement about not only her 
new sense of religiosity but also commitment to a new community. However, the newfound community became a new source of pressure. The empowerment due to having made a personal choice and defied the former social milieu was countered by the demands of the new milieu. Serap explains how, as a novice, she felt this pressure: "When I first covered, I wore skirts and jackets. Then I started university and observed that the girls wore long overcoats and large scarves. They immediately began preaching about the correct form of covering. They talk with you, give you books. They all dress in that style; you think they know religion better than you. . . . So I asked my mother to sew a long overcoat for me. She wept, saying 'this is not appropriate, you cannot be comfortable in this.' But I wore it, for a couple of years." Serap's story reveals how she accepted a new influence while at the same time asserting her free will, in this case, against her mother and the teacher who scolded covered girls.

This new influence seems to have been part and parcel of the global emergence of political Islam (Barber 1995). The so-called Islamic resurgence has had many reflections in Turkey, including the increasing flows of money and ideas to support the activities of diverse religious orders (Vertigans 2003). It probably began in Turkey in the 1950s, when governments attempted to win the support of the rural electorate and intensified since then. The first Islamist party was founded in 1970 and entered the parliament in 1973. It's National Outlook program emphasized industrialization and progress along with Ottoman-Islamic heritage and closer economic ties with Muslim countries (Toprak 1984). The above-mentioned left/right strife and the international cold war politics also contributed to Islamic resurgence. Moreover, the rapid urbanization of the 1980s also played a role in the emergence of Islamic collectivities: the recently urban residents, uprooted from their villages or small towns, interacted with each other perhaps more than with the established and more liberal urbanites. Such institutional forces framed an individual's journey into covering.

In sum, informants' stories reflect their pursuit of freedom from the discomforts of various political and everyday anxieties and moral threats as well as the comforting boundaries they chose in that quest. They convey the unlearning and the learning they faced as they moved away from their former social milieu into a new (and a promoted) one. They feel empowered and comfortable as they assert their own, what they feel to be holy, choices, in opposition to their parents, seculars, or the male gaze, even though they sigh about some of the freedoms they willingly gave up. While, in some cases, covering might have been provoked by a desire to express resistance (to the ban), we doubt that the deviant would have been adopted without the quest for stability and the encounter with a new collectivity. The late 1990s brought other looks and quests that informants pursued while practicing covering.

\section{Performing the Deviant: Routinization of Tesettür}

By the late 1990s, the look of tesettür had changed vastly, transforming to multiplicity and "soft" tesettür, when the loose uniform overcoat gave way to tighter jackets and pants, dark colors yielded to pastels and brighter ones, and head scarves became smaller. A large diversity of styles came to be noticeably paraded on the streets, in workplaces, in shopping malls, and even at some state ceremonies. Gül explains what soft tesettür (fig. 2) is and does: "Now there is some sort of softening. People want to participate in the social life and prefer comfortable clothes. Even the ones who used to say they'd never compromise their faith. . . . I mean now women who wear loose overcoats and large head scarves draw more frowns." Thus, softening served to render tesettür more ordinary. In Mine's words: "Now many [covered] women wear much shorter and tighter clothes. Nobody cares. Variety of styles increased a lot. The number of covered women also increased. Maybe that's why dressing styles have become very different. Maybe now everything is perceived as normal."

Fewer frowns and being perceived as normal suggest that, along with the softening of tesettür, the stigma attached to it started to subside over time. Our observations and archives testify that, starting in the late 1990s, tesettür was seen not only on university students protesting the ban, but also on politicians' wives, on ski slopes, in trendy restaurants, in concert halls, and in five-star summer resorts. We have also been seeing more tesettürlü and uncovered women walking together at such places. Remarking that "tesettür is now everywhere," an uncovered informant told us of an incident at a restaurant with live Western music. She saw a young couple, the woman in tesettür, watching the dancing people with yearning. She encouraged them to dance, and they did, with great joy. She added that she is now more tolerant of the covered women. She has to be, as tesettür is now at the former bastion of secularism, the president's residence. It is even at the White House Web site in a photo of the tesettürlü Turkish first lady, Hayrünnisa Gül, with Michelle Obama at the Notre Dame cathedral. Furthermore, tesettür clothes are no longer something sewn at home but a multimillion dollar global business, not only making tesettür commercially visible but also framing it as fashion (Gökarıksel and Secor 2009; Sandikc1 and Ger 2007). We identify two key processes that enabled tesettür to become a fashionable, more ordinary, and less stigmatized practice engaged by a broader public: personalization and aestheticization.

Personalization of the Practice. Just like the uniform overcoat, the 1980s uniform discourse about correct tesettür gave way to multiplicity in the 1990s. Neither the Koran nor the hadits specify how exactly a believer should dress. Rather, they only establish some general principles regarding modesty-covering parts of the anatomy in order to avoid the male gaze. Our informants consult diverse theological works and observe the varied dressing styles of the wives of Islamist politicians. Different authorities, in a multitude of Islamist newspapers and television channels, perhaps rep- 
resenting views of different religious orders or political interests, voice different interpretations, which, in turn, are cited by different fashion designers. Accordingly, appropriate clothing was a favorite topic of heated discussion at the all-female clubs where we hung out.

Given the profuse interpretations and practices our informants now encountered, they began to question the boundaries, including the necessity of the overcoat. Moreover, wearing look-alike overcoats began to feel like "being in a mold." The uniform overcoat, once comforting because of the protection, respect, and the freedom from male gaze it provided, now felt uncomfortable both materially and psychologically. Its looseness and length imposed an inconvenience for more active lifestyles. Gül, who works for an Islamist magazine, says that "now that I work as a journalist, I don't wear the overcoat anymore-it has become very difficult." When she ran "from one meeting to another," the overcoat limited her movements. She remarks that she frequently stepped on it and even fell down. Moreover, because the overcoat was too long, it quickly got wrinkled and dirty. The summer heat posed another problem, as Bahar describes: "If you go to the seaside with a dark blue overcoat, people look at you as if you were an alien. . . . I mean, if you are okay with getting negative reaction, or melt down in the heat, then you can wear it. So, I sewed a dress. . . . My dress doesn't reveal my body and doesn't get negative attention. That's my tesettür. I vacationed comfortably." As indicated with the terms "alien" or "negative attention," the overcoat became a source of anxiety: the anxiety of being taken to be a "backward" radical Islamist. In Merve's words, the overcoat, with its wideness, materialized the "symbolic distance" between the Islamists and the seculars. Yet, rather than being isolated, these women wanted to participate in public life, and although they wanted to situate themselves in the new Muslim community, they did not want to be labeled as reactionaries. Thus, attempting to maintain a physical and mental sense of comfort and drawing from multiple interpretations, our informants began to personalize their tesettür. Bahar explains:

\footnotetext{
How can I set my own standards? Real dilemma. I initially wore the grandma coat, its hem always covered with dirt. Later tighter cuts, shorter, more colorful jackets, the modern style. You wonder whether this is appropriate for Islam. When I wear a tighter shorter coat or more colorful things people react to me more moderately. . . . I feel more comfortable. Comfortable because the person facing me is thinking "she is not one of those who are reactionary." I don't want to receive reactions but I don't want to compromise either. I dress according to the boundaries in my mind. [Pointing to her coat.] This is tight, short, has long slits on the sides. When I first saw it I thought "this fits my tesettür, this is my preference." Or a cute vest. I bought it and then found a matching long sleeved t-shirt to wear under it. . . . That fits my personal tesettür too.
}

In deciding how to cover, Bahar faces an ongoing struggle during which the boundaries of tesettür are constantly (re)negotiated: neither reactionary nor unfaithful, she wants to express her individuality as much as her Islamic affiliation. Her solution, as echoed in the narratives of many others, is to set her own boundaries and shape her "personal tesettür." Bahar's choice of the short tight coat or the vest highlights her quest for individuality. The lack of consensus on what constitutes proper tesettür enables her and others to develop their own, differentiated style while remaining within the new Muslim community. Similar to the conformity-autonomy dilemma that Thompson and Haytko (1997) identify in their study of consumers' uses of fashion discourses, the tension between belonging to a community yet remaining as an individual acts as a powerful force that informs women's clothing practices.

Such personalization brought dynamism to the practice of covering as urban women began to experiment with different styles. Consider Ayşe's trials with her scarf: "When I began to wear the head scarf I tried various styles and finally found my own. . . . Later I didn't like that and found another style. . . . Maybe I will change it again later. I also tried tying it on the side. But it slid. I used a brooch to fix it, but then I didn't like the look of the brooch. Then I turned to modern, small scarves. . . . You want to be comfortable and nice looking; you come up with your own style." She experimented similarly with various types of trousers, skirts, and jackets. Like Bahar, her accentuation on finding her own style underscores her ongoing quest for individualization. As most informants experience, believe, and deem to be modern, now "everybody shapes her own tesettür." So much so that, in Mine's words, "different styles, different for each person, have become "normal.",

In sum, the informants, interacting with numerous religious texts and human actors, actively engage in discovering, crafting, and choosing their personalized tesettür. Their emphasis on individual interpretation and choice reflects their empowerment and nontraditional status: they are not (Orientalist) subjects who are forcefully covered. The observed multiplicity of discourses enables the practice to shift from being framed as a purely religious/political act to being framed also as a personal consumption practice, or, from an expression of solely collective identity to both collective and personal identity. We find that the concept of comfort figures prominently in this process: drawing upon its shifting meanings, women are able to define a particular set of items as acceptable, and others as unacceptable at a particular point in time. Tesettürlü women skillfully resolve the tension between being faithful and comfortable and creating, modifying, and vigorously legitimizing their clothing choices. Modern styles serve to help pursue their will to be faithful and struggle with (re)stigmatization at the same time. As they compose new softer styles, they inspire others to adopt tesettür. As a consequence, the sight of women in soft tesettür in the streets becomes almost normal. Yet, the quest for both religiously and personally satisfactory looks and both collective and personal identity entails a struggle to resolve yet another tension: between religious modesty and 
fashionable, tasteful, and beautiful appearance, both of which are embedded in patriarchal relationships.

Aestheticization of the Practice. While our informants want to be modest and refrain from looking sexually inviting, they definitely do not want to be unappealing. Their first association with clothes is good looks. They use the words estetik (aesthetical) and zevkli (tasteful) to connote graceful beauty and fashionable and elegant looks. Their belief that covering should be beautiful because "God is beautiful and likes beautiful things" swiftly legitimizes this interest in beauty. They cite the Koran or the hadits on the importance of beauty and the prophet's interest in dressing beautifully. The debates on aesthetics and taste prevail among the faithful tesettür fashion designers and respected Islamist columnists. For example, an essay titled "To the attention of the wealthy Muslims" advocated that Muslims decorate their homes and themselves "tastefully, artfully and aesthetically" and detailed what such taste would entail. The author continued that "if there are 25 contemporary couples, with uncovered wives, and 25 faithful couples with covered wives, and if an international jury . . . of designers were to evaluate them, the verdict should be that the faithful are dressed more tastefully than the others" (Eygi 2007).

Another legitimization the informants resort to is that fashionable and beautiful dress fulfills a holy function, as a woman so covered inspires others. For many who covered in the 1990s, looks posed a key consideration in their "voyage" to covering. Sibel and her friends adopted tesettür only after they realized that a covered woman could be appealing: "One typically starts thinking when one sees a woman covered in a beautiful manner. You say 'ok, then I can cover too.' The beginners start as emulators. Later they deliberate and decide on their own tesettür style. I remember a covered girl in my neighborhood: I never even looked at her face until I started thinking about covering. Then I saw that she was very beautiful!" As Sibel notes, not knowing much about the nuances of covering, inspiration and imitation play important roles in the decision to cover and learning how to cover beautifully. The social logic of mimesis (Girard 1977) prevails in the case of tesettür as it does in the spread of fashions in any clothing item. What differs is the belief in the holy role of an appealing tesettür. Seda's eyes shine as she recalls: "At a dinner party one night, an uncovered woman, someone I did not know, approached and hugged me. She said she'd been considering covering but was afraid of looking ugly and out of place. But now she admired the way I looked. . . . She told me, with tears in her eyes, that she now knows that she can cover too." As more women are thus inspired by the attractively covered role models, including the first lady, tesettür ceases to be exceptional, and women in fashionable tesettür become increasingly visible "everywhere."

Fashionable tesettür owes its spread and visibility partially to a new sector claiming to "make covering beautiful." To the delight of our informants who recall earlier times when they could not find clothes that were both fashionable and modest, today the tesettür fashion market provides a large variety. Realizing that fashion-oriented covered women constituted a lucrative market, firms recruited designers, introduced stylistic innovations, participated in international fairs, and adopted fashion marketing tools (Sandikcı and Ger 2007). The first tesettür fashion show was organized in 1992 by a leading company, Tekbir, which publicly announces its desire to blend Islamic aspirations with global capitalist ambitions (Navaro-Yashin 2002). As other tesettür firms followed Tekbir, fashion shows and advertisements highlighting the "beauty of covering" became commonplace. The first tesettür fashion show we attended took place in the packed ballroom of a five-star hotel. Most attendees were dressed in trendy outfits and high heels (fig. 2 ). They watched keenly as artificial clouds appeared on the podium and as top models, uncovered, except on this catwalk, marched in.

The insistent demand for tasteful tesettür made an impact also on stores formerly catering solely to uncovered women. In Damla's words: "We used to ask for long-sleeved blouses in the summer. In vain. Now all shops have them. . . . Or I see a nice skirt with a deep slit, something I cannot wear. They say 'we can convert the slit to a pleat' and they alter it. So now I can buy tasteful things."

The bowing of the uncovered fashion stores to their new, middle-class covered clientele as well as the emergence of the tesettür fashion market itself are not divorced from the increasing power of Islamist groups. The urbanization and the economic privatization, liberalization, and globalization of the late 1980s contributed to the growth of a so-called Muslim business sector (Emrence 2008; Yavuz 2004). Backed with export incentives from the state and funding from Islamist organizations in Germany and Saudi Arabia, these firms and their ambitions grew rapidly. One such firm recently acquired Godiva Chocolatier. In 1990, MUSIAD (Independent Industrialist and Businessmen Association) was founded to represent the Islamist companies, as an alternative to TUSIAD (Turkish Industrialist and Businessmen Association), which represents Istanbul-based businesses aligned with secularism. While "MU" is the abbreviation for Müstakil (independent), the common perception is that it stands for Muslim. MUSIAD cooperates with the National Outlook movement, which has become a noteworthy global religious-political force that we witnessed in Germany. Regardless of its internal heterogeneity in terms of religious convictions, affiliations with different religious orders, and control of a range of media outlets, this new business sector has been exerting significant influence on political, social, and economic life.

The rise of the so-called Muslim businesses accompanied the ascent of the Islamist party in the political arena. The Islamist Justice and Development Party (JDP) has been ruling the country since 2002. Such growth of power exacerbated the secular fears of Islam-based governance. In defense of secularism, the military pronounced two critical declarations in 1997 and 2007. The former resulted in the eventual abolishment of the Islamist party that was then in the coalition government. The latter aimed at the JDP-the 
successor of the abolished party-which nominated one of its members as a presidential candidate. This declaration was supported by massive civil protests of the nomination: millions of people walked, voicing their alliance to secularism. Despite such reactions, the JDP nominee became the president.

Thus, the rise of the tesettür fashion market, Muslim businesses, and the power of JDP contributed to the transformation of tesettür into a relatively more ordinary practice. There were other local and global enabling factors, such as the 1997 military declaration, the attacks of 9/11, and the French ban of veiling in schools. After the 1997 declaration, in order to fend off criticism, many women opted for smaller scarves tucked into their collars, and, gradually, such scarves became trendy, as the retailers and the consumers we talked to confirm. Similarly, in the aftermath of $9 / 11$, with the increase in the flow of media images of Muslims as militants, portraying an appealing image became particularly important. As many informants recall, nobody wanted to look like a "religious fanatic" and preferred more "modern" outfits. The 1989 French ban, which appeared prominently on Turkish media, had a more indirect impact. The French court's antiveiling stance throughout the 1990s, later followed by some other European courts, discouraged the advocating of veiling as a human right in Turkey (Gökarıksel and Mitchell 2005). This contributed to the shift from a legal discourse to a market discourse and served as a further impetus for fashionable veiling.

Equipped with their new economic and political power and determined to exhibit a pleasing, modern, and tasteful look, a new middle and upper-middle class, or a "religious bourgeoisie," emerged as avid practitioners of conspicuous consumption. Either as wives of businessmen, politicians, or bureaucrats who displaced or coexist with their secular colleagues, or as professionals employed by Muslim businesses and municipalities, these faithful women are keen consumers. In search of an aesthetic look with scarves that complement their skin and outfits, we witnessed that sometimes over 60 scarves sit unused in a drawer as fashions change. Wardrobes are also filled with brand-name handbags and shoes to complement the color of their scarves and trendy outfits and mark their newfound status. Despite the Muslim ideal of freedom from waste, the pursuit of aesthetics makes them indulge in shopping. By framing fashion as an inescapable reality and as a holy means of inspiring others to cover, tesettürlü women justify their fashion consumption as a conforming behavior rather than an act driven by selfish desires. In contrast to the undesirable image of the fashion conformist that Thompson and Haytko (1997) observe, conformity assumes a positive connotation, as it justifies our informants' interest in fashion and renders normality to their consumption practices.

Like their uncovered counterparts, our informants employ aesthetics in their struggle to mark their identity. Aesthetics connotes, foremost, a refined urban taste of the "normal" modern world. In their attempt to distance themselves from the urban poor now wearing the overcoat or soft tesettür, the "crude" peasants, the religiously unsophisticated women covered carelessly and "traditionally," or the reactionaries "dressed like the Iranians," our informants seek to craft looks that will locate them as modern women, as we see in Damla's account: "I am not dressed like the women of 50 years ago. . . . I am dressed in a modern way. Sometimes they ask me why I don't tie my scarf at the front [the conventional way of tying basörtüsü]. But that way is being backward: it is the way of 50 years ago. My clothes are more in line with today's trends. Not like my mother or my grandmother."

Our informants aestheticize tesettür not only in their pursuit of distinction from certain Islamist or traditional "others" but also to negotiate their similarity to the uncovered moderns. Consider Zeynep, a journalist for an Islamist newspaper, who, like many others, is taking advantage of the increased job opportunities in the "Muslim" sector. When we met at her office, she was wearing a beige V-neck top, navy blue trousers, a light brown jacket, and beige platform shoes. The edges of her small head scarf, patterned with splashes of blue, brown, and beige, were tucked inside her collar. She believes in an appealing image and emphasizes that "a Muslim woman should look attractive without being perceived as strange, within the limits of Islam." Zeynep's concern for a style that is not "strange" is shared by many others. As, for example, Mine explains, an elegantly crafted tesettür brings its wearer closer to the uncovered women, at least in terms of clothing practices: "I dress well, harmoniously. Then it looks familiar to people. When they see that the clothes they wear are also worn by a covered woman, they might think 'the covered aren't abnormal people; they dress like us.",

However, while our informants want and claim to appear like the uncovered moderns with the exception of "just a scarf," they distance themselves from an aesthetics that they believe equates modernity with indecency. They see modern times to be replete with loss of morals, promiscuity, and exhibition of the scantily dressed and overly made-up female body as a sex object. They believe that such indecency increased in the mid-1980s with the opening up of not only the economy but also the private lives and bodies and became worse in the 1990s with televole, which they think links freedom with nudity and sexuality. Televole refers to Turkish paparazzi media that provide news from the lives of celebrities, typically entailing pictures of scantily clad females at nightclubs and beaches; expose the details of the love lives of the stars; and evaluate them in terms of their looks. These exposés are disapproved of by the seculars as well as the Islamists due to their superficiality, portrayal of loose manners, and reduction of the female to a sex object. Yet, most watch or read enough to keep up with the latest gossip, even if they then sigh "what modern times have brought." Televole and the governmental regulation of such television shows, which make news too, convert decency into a public debate. Such debates are not dissimilar to the head scarf and the G-string debates in the Netherlands, both of which have been argued to serve attempts to regulate 
female sexuality (Duits and van Zoonen 2006). Taking sides in such a debate, our informants maintain that they want to be feminine without the televole-style femininity. Similar to Scott's (2005) Western consumers, they attempt to use fashion for emancipatory purposes, but they use an alternative, tesettür fashion rather than global (Western) fashion. By emphasizing the empowering aspects of fashionable tesettür, they differentiate themselves from the uncovered women who they believe have become slaves of televole-style fashion. This differentiation mobilizes a projection of the perceived moral threat of modernity on such secular women and a view of them as the undesirable other. In so doing, they construct a wholesome asexual femininity, still attractive to the opposite sex but distanced from concerns over being a sex object. Thus, the "modern" they want to be is being progressive rather than backward, being part of the "normal" contemporary world, and being elegant, tasteful, and aesthetically pleasant, minus the indecency of "open" ways of life.

However, as tesettürlü women pursue an alternative asexual femininity and seek to craft fashionable and tasteful looks, they face criticism within their own milieu. Orthodox Islamist media accuse tesettür fashion companies of exploiting religion for commercial purposes and turning covering into degenerate display (Barbarosoğlu 2005). The critics among friends as well as religious leaders argue that when tesettürlü women look attractive, they jeopardize the essence of covering: avoiding carnal attention. Consider Sibel's case: "I had a dispute with a friend. I have a gray skirt. There are slits on both sides and your legs are visible through the lining. She said 'You look very nice in this skirt and your body is really nice. This is alluring for a man. Don't wear this.' I didn't think there was a problem. I don't dress to attract attention. I really like that skirt. There are many things they criticize. But I don't listen to them because I am not dressing for men." Sibel later defended her choices by referring to the tenet that God wants Muslims to be and look beautiful. By framing looking attractive as a holy and inspirational act, Sibel, Seda, and others subvert the conventional notions about Islamic covering. The diversity of the discourses at their disposal helps such framing.

The secular media oppose tesettür fashions equally strongly. Commentators mock the clothing preferences of tesettürlü women, including the prime minister's wife, and preach about style and taste (Arman 2004). Others ridicule the so-called fashionable tesettürlü women on the grounds that "tesettür can never be fashionable" (Sandıkcı and Ger 2007). This viewpoint mobilizes the notion of taste and denies any possibility of covering to be tasteful. As fashionable tesettür spreads and becomes more visible, taste wars intensify. By ridiculing tesettürlü women's clothing choices, secular media and women claim their aesthetic judgments to be superior and designate the covered women as the tasteless inferior.

As criticism of "tastelessness" intensifies, so does the fight over legitimate taste. While the secular public disdains the looks of a "comically" dressed first lady, many covered women emulate her style. As tesettürlü women project more fashionable looks, they advance their claims in the taste structure dominated by the secular aesthetic. Designers, advertisers, and some Islamist intellectuals advocate the alternative aesthetics of tesettür. And our informants' accounts reveal comparative assertions of their styles and debasement of televole styles. The new religious middle/upper-middle class negotiates legitimate taste with the established secular upper classes through the interplay of similarity and difference. In the process, two parallel taste structures, Islamist and secular, come to challenge each other.

In sum, transformation in the stigma status of veiling happens through two interrelated processes-personalization and aestheticization - as our informants negotiate their identities as both a middle-class modern individual and a member of a collectivity. Informants' stories reveal the gradual fragmentation in the discourse and practice of tesettür. As women negotiate the tension between being faithful, modern, and nonreactionary, and work through different interpretations of proper covering, they shape their own tesettür. The process of aestheticization accentuates middleclass tesettürlü women's claim to taste. Aestheticization entails legitimization of "beautiful" covering along with discrediting of both "indecent," "open" styles of dressing and rural/traditional practices of veiling. A new aesthetics, in differentiation from televole and rural/traditional aesthetics, gets constructed. Routinization of tesettür, its increasing spread and visibility, manifests the materialization of this new Islamist bourgeois aesthetics. As we have seen, routinization entails the joint work of consumers, the market, and many other individuals and institutions. Consumers interact with many constraining and enabling actors, such as the legal apparatus that deterred certain styles and encouraged others, or the tesettür fashion market.

\section{DISCUSSION AND CONCLUSION}

Our analysis revealed how tesettür, a stigmatized practice in the secular mind-set, was first voluntarily adopted by some middle-class women and then transformed into a fashionable and ordinary consumption choice for many. We have detailed the effortful and multi-actored work that underlies the emergence of tesettür as an attractive choice. We have seen that women, in their search for comforting stability and boundaries, willingly chose a stigma symbol and became part of a new community. We have shown that personalization and aestheticization have contributed to the routinization of tesettür and the change in its stigma status. We have discussed various tensions and negotiations that characterized women's experiences and identified the actors of the adoption and transformation processes. Our analysis has also shown that the change in the status of a stigmatized practice is a contingent process. In the case of tesettür, the power of the Islamist movement and the power of the market - both of which in turn depend on other factors such as urbanization and neoliberal policies-formed an alliance that helped create the necessary conditions for change. We have found that informants feel comfortable and empowered 
by their "virtuous" and "modern" choices, where the modern is as desirable as the virtuous. Our analysis also indicates that routinization of tesettür manifests the emergence of a new aesthetic. We now discuss theoretical implications of our findings.

\section{Stigma, Choice, and Free Will}

Our informants' decision to adopt a stigma symbol entails elements of both escape and resistance. However, framing the decision to veil only in these terms overlooks the moral dimension of choice. By defying the norms of their social milieu, these women certainly resist some aspects of Kemalist modernity and escape from the problems of what they perceive to be an overburdened and oversexualized female identity. But, at the same time, they construct and express themselves as moral selves. By choosing tesettür, they believe that they can live their faith more truly and become a better Muslim. Belk et al. argue that "as self-managing subjects, we moderate our consumption acts and refine our consumption desires in order to feel or become an ethical person" (2003, 346). Guided by a similar moral urge, our informants make what they believe to be a "virtuous choice" (Asad 1993, 126). However, being the moral subject that they aspire to be has its liabilities. Choosing to become covered involves undertaking a profound change in how one lives her life. In this regard, similar to the consumer activists that Kozinets and Handelman (2004) studied, women's adoption of tesettür indicates a commitment that goes well beyond engaging in a temporary act of resistance, such as going to Burning Man or riding a Harley-Davidson on a weekend. In voluntarily committing to tesettür, women know that their choice will bring restrictions and that they will need to discipline themselves in their consumption practices.

Cognitive-oriented studies show that, in general, imposition of a restriction influences behavior negatively and challenges a consumer's sense of control (Fitzsimons and Lehman 2004). However, if a particular restriction and a consumer's goals are congruent, then cognitive and emotional reactions are likely to be positive and followed by behavior compliant with the restriction (Botti et al. 2008). Our cultural approach suggests that when goals are significant for the identity project, consumers not only willingly submit to goal-related restrictions but perceive them as enabling rather than constraining. The women in our study believe that covering does not constrain their selfhood; on the contrary, they perceive the boundaries of tesettür as empowering and enabling them to become the women they aspire to be-moral, modern, feminine, and yet freed from the predatory male gaze. Tesettür, which brings restrictions, also provides a ground to realize one's self. We argue that restrictions can contribute to the identity project in two ways. On the one hand, they may relieve consumers from the necessity of making choices and allow them to enact their identities by choosing not to choose. On the other hand, they may encourage consumers to question and negotiate what constitutes a normal course of action, as a result of which new norms can emerge.

Restrictions, whether they are in the context of covering or dieting, limit the number of alternatives a consumer can choose from. Studies show that reduction in the number of options is not necessarily a bad thing because too much choice may have a negative impact on the decision-making process and result in suboptimal choices (Iyengar and Lepper 2000; Schwartz 2004). Especially in complex situations, limiting alternatives and delegating a decision-making task to others may improve decision quality (Botti and Iyengar 2006). We argue that too much choice may not only impair the quality of decisions; it may also interfere with the identity project of the consumer. In such cases, delegating decision making to an authority and submitting to its restrictions may help the consumer achieve her desired subjectivity. In the 1980s, when women adopted the overcoat uniformly, they sought to escape from the anxieties of what they perceived to be a lifestyle that is characterized by too much freedom and choice. As they submitted to the boundaries of the overcoat, they chose to be a nonchoosing subject. Paradoxically, in doing so, they performed their identities as not only moral but also free individuals who chose to go against the prevailing ways of behaving.

Restrictions can also contribute to an identity project when they are used productively to create new norms. The boundaries of tesettür as materialized in the form of the overcoat have provided a ground from which women could reinterpret what religiously appropriate covering is. As restrictions are questioned and reassessed, the uniform discourse has gradually fragmented, and alternative and multiple discourses have gained legitimacy. With soft tesettür becoming the new norm, women's clothing choices changed tremendously. Loewenstein (2001) argues that how people construe the situation they are in affects the decisions they make. When a person's construal of the situation remains unchanged, behavior tends to be stable. But, when an individual's construal of the situation she is in changes, so does the behavior. Although we concur with him, we also argue that how a person construes the situation is not only based on her personal evaluations but embedded in the discourses available to her and, hence, highly dependent on power dynamics, which are also subject to change. The shift from the uniformity of the overcoat to the multiplicity of soft tesettür indicates the change in how women construe and negotiate the demands of Islam and the demands of a modern life and construct a style of covering that is both comforting and appealing. However, these negotiations are enabled and constrained by a dynamic and complex network of actors and are well beyond the work of an individual consumer.

Overall, clothing practices of tesettürlü women indicate both acceptance and negotiation of restrictions. Adopting and performing tesettür entail submission to various authorities and rules but also imply an agent who has "the ability to select an option from a set of alternatives" or free will (Mick 2008, 17). When consumers willingly submit to 
the restrictions set by a dietician, a yoga guru, or a doctor, a similar coexistence of submission and free will seems to be at work. In a rare investigation of consumers' experiences of free will, Thompson, Locander, and Pollio (1990) found that women experienced a stronger sense of free will when they felt in control, deliberate, and unrestricted in their choices. However, they also reported that in some exceptional situations, women "experienced more freedom when placed in a restricted situation and gained a feeling of control by giving up control" (Thompson et al. 1990, 358). We argue that such an experience ceases to be exceptional when restrictions are conducive to an identity project, as in the case of our informants. Then, submission no longer acts as a hindrance against enactment of free will but becomes a willed choice, contributing to the identity. Similar to the Christian monk "who learns to will obedience" (Asad 1993, 125), our informants learn to will the comforting boundaries of tesettür, but they also continuously renegotiate the boundaries. Hence, as in many other consumption practices, tesettürlü women pursue their identity projects and perform their potentialities by both submitting to restrictions and exercising their free will. Veiling makes them neither less nor more agentic than their uncovered counterparts.

The intricate relationship between submission and free will implies that sociocultural construction of choice might entail a much more dynamic, relational, and relative process than revealed so far (Allen 2002; Fischer et al. 2007; Thompson 2005; Wong and King 2008). These studies explicate how cultural discourses and institutional and social structures shape consumers' risk perceptions, goals, and decisions. Our study contributes to this emergent dialogue between cognitive and cultural perspectives on choice. Furthermore, our findings reveal that not only the object of choice but the practice of "choosing" itself is a construction. As submission and free will continuously inform and are informed by each other, what qualifies as "choosing" becomes a shifting experience. While wearing the uniform overcoat in the 1980 s gets constructed as making a choice, it later becomes reconstructed as "being in a mold" and, hence, a sign of lack of free will. Such diametrical shifts in the meaning of the same behavior suggest that the practice of "making a choice" is a socioculturally constructed process that should not be taken for granted but problematized and unpacked. Unpacking it reveals that a deliberate and effortful work of various enabling and constraining actors goes into making stigmatized tesettür an attractive, fashionable, and ordinary consumption choice.

\section{Stigma, Routinization, and Formation of New Elites}

Our analysis identifies routinization as a mechanism through which change in the stigma status of a consumption practice might happen. Moreover, we argue that routinization of tesettür manifests the emergence of a new Islamist elite in Turkey. In the social science literature, there is a renewed interest in theories of practice (Reckwitz 2002;
Warde 2005). In this body of work, routinization and practice are conceptualized as coconstituting, where a practice is "a routinized way in which bodies are moved, objects are handled, subjects are treated, things are described and the world is understood" (Reckwitz 2002, 250). As such, a practice represents a routinized pattern of behaviors carried out by individuals. For example, a tesettürlü woman carries a particular way of dressing that entails a particular interconnection between her body, objects such as scarves, subjects such as religious orders, and her worldview. Routinized practices, with their repetitive, recursive, shared, and orderly nature, reduce the complexity of decision making, create a comforting world, and give individuals "a feeling of normality" (Ilmonen 2001, 14). In a Gramscian sense, the feeling of normality manifests an established habitus (Bourdieu 1984; Holt 1998). The spread, visibility, and frequency of a particular way of dressing, which contribute to the feeling of normality, imply a potent and effective habitus. Hence, from the practice theory perspective, routinization constitutes the very nature of social structure: structure can be found in the routinized and normalized nature of practice. We argue that the transformation in the stigma status of tesettür and the accompanying sense of normality manifest the change in taste structures in Turkey. At the individual level, routinization of tesettür contributes to a personal sense of comfort and empowerment and strengthens covered women's new wholesome feminine and modern identity. At the collective level, routinization contributes to a new sense of aesthetics and an accompanying new habitus, which is informed by Islamic as well as modern sensitivities.

Studies on the sociohistorical patterning of consumption demonstrate that social and institutional structures systematically influence consumption (Allen 2002; Askegaard et al. 2005; Holt 1997, 1998; Thompson and Haytko 1997; Üstüner and Holt 2007). Holt's studies, in particular, show how social collectivities work in increasingly subtle ways to structure consumers' preferences and that even when individuals engage in creative and industrious forms of consumption, they still work "with the existing frameworks of tastes in which they have been socialized" (Holt 1997, 344). Our work extends this body of research by revealing how taste can also have a formative role in social ordering. When local and global economic, political, and social power relations are conducive, the struggle over what constitutes normal and legitimate taste can play a significant part in the emergence of a new elite, with significant material and discursive resources.

Furthermore, our study shows that consumption practices and fashion in particular can have an important role in the construction of a new, parallel taste structure. The change in the stigma status of tesettür and its routinization make visible not only the increasing power of the Islamist actors but also the emergent aesthetics that hybridize Islamic and secular/Western sensibilities. These new aesthetics and fashions are manifest in soft tesettür but also are transposed to other consumption domains such as home decoration, leisure, literature, media, and food. Akin to Veblen's analysis 
of the emergence of a leisure class and their new consumption styles in nineteenth-century North America, these new fashions manifest the emergence of the Islamist elite and their consumption styles in Turkey. Clothes, due to their material presence and visibility, play a particularly important role in legitimizing this new taste structure. Thompson and Haytko (1997) propose that multiplicity of fashion discourses provides a myriad of interpretive positions from which consumers can negotiate various tensions in their lives and express resistance to dominant fashion norms. Our analysis reveals another and more collective function of fashion: fashion can be both a key medium and a marker of a new habitus.

This newly forming habitus is not homogeneous and reflects countervailing interests of different religious orders, political factions, classes, and groups with different gender positions. The continuing debate on what constitutes proper tesettür among different groups of Islamists is one of the indications of the internal struggle. Furthermore, this new habitus is hierarchical, at least in terms of class and gender. Soft tesettür reproduces middle-class notions and practices of modernity, individuality, and fashion. While our informants claim to be as fashionable as the secular middle classes, they diligently seek to disassociate themselves from poorer, rural, or traditional covered women and their "unrefined" tastes. Besides class, patriarchal relationships are also present in the new habitus. While a new wholesome femininity is claimed, tesettürlü women continue to be the object of the male gaze. As exemplified in the case of Sibel, the attempts to regulate the female body, even when it is covered, continue to be as strong as ever. Hence, fashionably covered women find themselves in a network of new power relations that do not displace the old hierarchies of class and gender.

The observed transformation in the stigma status of tesettür through routinization indicates that there might be other mechanisms besides co-optation in social change. Rather than containment of one by another, routinization of tesettür manifests the power struggles among the historical and emergent coexisting elites and the ongoing quest for legitimacy acted out in the domain of consumption. Recent sociological approaches emphasize that "it takes power to stigmatize" (Link and Phelan 2001, 375). We show that it also takes power to destigmatize. In the case of tesettür, destigmatization succeeds because of the potency of the processes of personalization and aestheticization of new veiling and the concurrent "othering" or counterstigmatization of "indecent," "open" clothing. While tesettür gets constructed as the morally and aesthetically superior choice, some secular styles of dress and the oversexualized femininity it connotes get debased. The interplay of similarity and difference spawns counterstigmatization of the "indecent" moderns while attempting to deal with (backward, traditional) stigmatization and (political, reactionary) restigmatization. Such interface between stigmatization and destigmatization highlights the fragile boundary between the stigmatized and normalized and their embeddedness in shifting power struc- tures. When a stigmatized practice is embedded in a network powerful enough to challenge and change the taste structure, the boundary becomes increasingly blurred, and the practice can eventually transform into an ordinary consumption choice.

\section{Religion, Consumption, and the Market}

Similar to stigma, marketing scholars have paid limited attention to religion (Belk, Wallendorf, and Sherry 1989; Kozinets 2001; Kozinets and Handelman 2004; Mittelstaedt 2002; Muñiz and Schau 2005; O’Guinn and Belk 1989). This scant research revealed that religion still commands an important place in contemporary life, adapts to the consumer-centered world in novel ways, and affects marketplace activities. Our study contributes to this literature by further unpacking the relationship between religion, consumption, and the market. We demonstrate that religion, like other institutional and social structures such as gender, class, and ethnicity, influences consumption choices and provides individuals with another set of resources and ideals for identity construction.

Our study also shows that there is a symbiotic relationship between religion and the market. The adoption of fashion marketing tools and professionalization of tesettür stores were integral to the strengthening of soft tesettür. However, the market did not simply "co-opt" tesettür and proliferate clothing choices. The market, as a set of institutions, actors, practices, and discourses (Slater and Tonkiss 2001; Venkatesh and Penãloza 2006), played a much more complex and multifaceted role in increasing both the appeal and visibility of tesettür. For example, the proliferation of Islamic fiction and nonfiction books, media, and popular culture helped disseminate Islamic principles and vision of life especially among young women who used to be rather distant from Islam. The media also acted as a forum for debating what constitutes the proper covering and played a part in the fragmentation of the uniform discourse on tesettür. Moreover, businesses such as restaurants, hotels, and sports and beauty clubs catering to the Islamist consumers became venues for tesettürlü women to parade in and intermingle with each other. Finally, Islamist companies provided employment opportunities for tesettürlü women for whom career and related lifestyle changes were instrumental in the turn to soft tesettür. Hence, beyond co-optation, the market, in its broad sense, has been an important actor in the routinization of tesettür and contributed to the formation of the new Islamist elite.

By explicating the multiple roles of the market in the spread of tesettür, our work also brings new insights into Islamist movements. Earlier approaches often conceptualized Islamist movements as activities of homogeneous and static collectivities motivated by resistance to Western secular modernity (Esposito 1998). Recent approaches emphasize that Islamist movements are not merely reactionary activities of "dysfunctional" individuals but, on the contrary, are constituted of rational and strategic activist structures based on mobilization of various resources such as political 
parties, religious organizations, nongovernmental organizations (NGOs), schools, and social networks (Bayat 2005; Wiktorowicz 2004). Our findings indicate that the market is another resource that the Islamist movement mobilizes. However, in contrast to Yavuz (2004), who argues that new "opportunity spaces" have provided the Islamist actors with new mechanisms of empowerment, we find a more nuanced effect of the market on solidarity building. On the one hand, softening of tesettür helped recruit more women and strengthen the collectivity. On the other hand, the proliferation of tesettür styles and the weakening of the uniform overcoat illustrate the multiplication of discourses and possible fragmentation in the movement.

The symbiotic relationship that we observe between Islam and the market also challenges the construction of Islam as a religion in opposition to consumerism (Turner 1994), or in clash with the global consumer world, the "McWorld" of Barber (1995). As Kozinets and Handelman also seem to agree, there is a widespread belief that religious-particularly, Islamic_-fundamentalism constitutes "one of the most powerful threats to global consumerist ideology today" (2004, 702; see also Turner 1994). Our findings indicate that Islam is neither a threat nor a panacea for consumerism and capitalism. Although there is denouncement of certain aspects of Western lifestyles, Islamist politics is deeply embedded in consumer culture. Tesettürl $\ddot{u}$ women do not counter modernity, but particular expressions of it, and craft a new, hybrid consumer identity that is both modern and religious, feminine and wholesome, and tasteful and moral. Their position resonates with Furat's (2005) notion of "this and that" rather than "either this or that" as the new sensibility guiding human lives. Hence, what we observe is a dialogic relationship between Islam and consumption, akin to Barber's notion of "Jihad via McWorld" rather than his more popular dialectic notion of "Jihad versus McWorld" (1995, 157).

Overall, our analysis reveals that consumption can be firmly embedded within a sociopolitical movement that seeks social change not by being against the market or consumption but mobilizing both as key resources in strengthening the collectivity. Existing studies of consumer resistance tend to regard the market as the target of resistance and assume that resistive consumers are antimarket and anticonsumption. While this is the case in certain situations, in others, market and consumption can become accomplices in resisting something else. In Turkey, the Islamist movement embraces the market and consumption and uses them for its own interests. The power of the Islamist movement lies in its cooperation with the market and the global consumerist ethos rather than its resistance to them. Tesettürlü women and the emergent Islamist elites in general do not resist the market. On the contrary, they use the market to resist the existing social order and build a new one. Their attempts to change the prevailing aesthetic norms, taste structures, and class dynamics succeed because they are supported by and integrated with intensified political, economic, and moral relationships. The significance and power of the veil in Turkey now reside more in the role it plays in the formation of a new and potent (and potentially transnational) Islamist elite and less in its so-called resistance to the West and the consumerist ideology.

\section{IMPLICATIONS}

Our findings pertain to the urban middle class and their choice-making behaviors. An important extension would be to examine how lower-class covered women choose covering and perform tesettür. In their study of poor migrant women living in a Turkish squatter, Üstüner and Holt find that the women's identity projects were dominated by a middle-class "orthodox West-facing constellation of tastes, goods, and practices," which does not allow pursuit of hybrid identity projects $(2007,53)$. In contrast to the dominating single taste structure that they discuss, we identify the formation of a parallel Islamist middle class that uses a new hybrid set of resources for its identity projects. Whether less-privileged covered women draw from these resources and pursue more or less hybrid identity projects remains to be studied. Future studies should also look at the internal class struggles within the Islamist community and tease out the influence of different class sensibilities on consumption.

The present inquiry also points to the importance of the materiality of objects for understanding consumption. Consumer behavior scholars tend to privilege the symbolic at the expense of the material and focus on the meaning-identity link. Although we acknowledge the importance of the symbolic, our findings indicate that women's interpretation and performance of tesettür have been both discursive and material. We hope that future studies shed more light onto this rather neglected dimension of consumption.

Our findings remind us of Ajzen and Fishbein's (1977) accent on social norms in addition to attitudes in forming behaviors - an accent that perhaps has been forgotten in the more recent research on consumer choice. Whether they investigate choice or identity projects, consumer behavior scholars will benefit from engaging more with normative frames, morality of choices, institutional forces other than the market, and the processes of change, such as routinization. At least we were excited by finding that consumers can build their identities as free individuals by choosing restrictions, that submission rather than resistance can become a catalyst for change, and that the individual search for morality, comfort, aesthetics, and a personalized style can play an important role in the formation of a new elite.

\section{REFERENCES}

Abaza, Mona (2007), "Shifting Landscapes of Fashion in Contemporary Cairo," Fashion Theory, 11 (2-3), 281-98.

Abu-Lughod, Lila (1986), Veiled Sentiments: Honor and Poetry in a Bedouin Society, Berkeley: University of California Press.

Adkins, Natalie Ross and Julie L. Ozanne (2005), "The Low Literate Consumer," Journal of Consumer Research, 32 (June), 93-106. 
Afshar, Halef (1998), Islam and Feminisms, London: Macmillan. (2008), "Can I See Your Hair? Choice, Agency and Attitudes: The Dilemma of Faith and Feminism for Muslim Women Who Cover," Ethnic and Racial Studies, 31 (2), 411-27.

Ahmed, Leila (1992), Women and Gender in Islam: Historical Roots of a Modern Debate, New Haven, CT: Yale University Press.

Ajzen, Icek and Martin Fishbein (1977), “Attitude-Behavior Relations: A Theoretical Analysis and Review of Empirical Research," Psychological Bulletin, 84 (September), 888-918.

Allen, Douglas (2002), "Toward a Theory of Consumer Choice as Sociohistorically Shaped Practical Experience: The Fits-Likea-Glove (FLAG) Framework," Journal of Consumer Research, 28 (March), 515-32.

Argo, Jennifer J. and Kelley J. Main (2008), "Stigma by Association in Coupon Redemption: Looking Cheap because of Others," Journal of Consumer Research, 35 (December), 559-72.

Arman, Ayşe (2004), "Emine Erdoğan'1 Bir Başkası Giydirmeli," http://hurarsiv.hurriyet.com.tr/goster/haber.aspx ?id = 224396 \&yazarid $=12$.

Arnould, Eric J. and Craig J. Thompson (2005), "Consumer Culture Theory (CCT): Twenty Years of Research," Journal of Consumer Research, 31 (March), 868-82.

Asad, Talad (1993), Genealogies of Religion: Discipline and Reasons of Power in Christianity and Islam, Ann Arbor: University of Michigan Press.

Askegaard, Søren, Eric J. Arnould, and Dannie Kjeldgaard (2005), "Postassimilationist Ethnic Consumer Research: Qualifications and Extensions," Journal of Consumer Research, 32 (June), 160-70.

Balasescu, Alexandru (2003), "Tehran Chic: Islamic Headscarves, Fashion Designers, and New Geographies of Modernity," Fashion Theory, 7 (March), 1-18.

Barbarosoğlu, Fatma Karabıyık (2005), "Tesettür Defilelerinde 'Öteki' Üzerinden Şov,” http://www.yenisafak.com.tr/diziler/ basortu/basortu03.html.

Barber, Benjamin R. (1995), Jihad vs. McWorld, New York: Random House.

Bayat, Asef (2005), "Islamism and Social Movement Theory," Third World Quarterly, 26 (6), 891-908.

Belk, Russell W., Güliz Ger, and Søren Askegaard (2003), "The Fire of Desire: A Multisited Inquiry into Consumer Passion," Journal of Consumer Research, 30 (December), 326-51.

Belk, Russell W., Melanie Wallendorf, and John Sherry (1989), "The Sacred and the Profane in Consumer Behavior: Theodicy on the Odyssey," Journal of Consumer Research, 16 (June), $1-39$.

Bengtsson, Anders, Jacob Ostberg, and Dannie Kjeldgaard (2005), "Prisoners in Paradise: Subcultural Resistance to the Marketization of Tattooing," Consumption, Markets and Culture, 8 (3), 261-74.

Botti, Simona, Susan Broniarczyk, Gerald Häubl, Ron Hill, Yanliu Huang, Barbara Kahn, Praveen Kopalle, Donald Lehmann, Joe Urbany, and Brian Wansink (2008), "Choice under Restrictions," Marketing Letters, 19 (3-4), 183-99.

Botti, Simona and Sheena S. Iyengar (2006), "The Dark Side of Choice: When Choice Impairs Social Welfare," Journal of Public Policy and Marketing, 25 (1), 24-38.

Bourdieu, Pierre (1984), Distinction: A Social Critique of the Judgment of Taste, Cambridge, MA: Harvard University Press.

Bowen, John Richard (2006), Why the French Don't Like Head- scarves: Islam, the State, and Public Space, Princeton, NJ: Princeton University Press.

Brenner, Suzanne (1996), "Reconstructing Self and Society: Javanese Muslim Women and 'The Veil,"' American Ethnologist, 23 (November), 673-97.

Campbell, Colin (1990), "Character and Consumption: An Historical Action Theory Approach to the Understanding of Consumer Behavior," in Culture and History, ed. O. Lofren, Aurhus: Akademisk Forlag, 37-48.

Çayır, Kenan (2007), Islamic Literature in Contemporary Turkey: From Epic to Novel, London: Palgrave Macmillan.

Clarke, Alison and Daniel Miller (2002), "Fashion and Anxiety," Fashion Theory, 6 (2), 191-214.

Davidson, Andrew (1998), Secularism and Revivalism in Turkey, New Haven, CT: Yale University Press.

Davis, Fred (1989), "Of Maids' Uniforms and Blue Jeans: The Drama of Status Ambivalences in Clothing and Fashion," Qualitative Sociology, 12 (4), 337-55.

Delaney, C. (1994), "Untangling the Meanings of Hair in Turkish Society," Anthropology Quarterly, 67 (4), 159-72.

DeMello, Margo (2000), Bodies of Inscription: A Cultural History of the Modern Tattoo Community, Durham, NC: Duke University Press.

Demir, Ömer, Mustafa Acar, and Metin Toprak (2004), "Anatolian Tigers or Islamic Capital: Prospects and Challenges," Middle Eastern Studies, 40 (6), 166-88.

Devine Patricia G., E. Ashby Plant, and Kristen Harrison (1999), "The Problem of Us versus Them and Aids Stigma," American Behavioral Science, 42 (7), 1212-28.

Dovidio, John F., Brenda Major, and Jennifer Crocker (2000), "Stigma: Introduction and Overview," in The Social Psychology of Stigma, ed. Todd F. Heatherton, Robert E. Kleck, Michelle R. Hebl, and Jay C. Hul, New York: Guilford, 1-28.

Duits, Linda and Liesbet van Zoonen (2006), "Headscarves and Porno-Chic: Disciplining Girls' Bodies in the Multicultural Society," European Journal of Women's Studies, 13 (2), 103-17.

El Guindi, Fadwa (1999), Veil: Modesty, Privacy and Resistance, Oxford: Berg.

Emrence, Cem (2008), "After Neo-Liberal Globalization: The Great Transformation of Turkey," Comparative Sociology, 7 (1), 51-67.

Esposito, John L. (1998), Islam and Politics, Syracuse, NY: Syracuse University Press.

Eygi, Mehmet S. (2007), “Zengin Müslümanların Dikkatine,” Milli Gazete (September 9), 5.

Firat, Fuat A. (2005), "Meridian Thinking in Marketing? A Comment on Cova," Marketing Theory, 5 (2), 215-19.

Fischer, Eileen, Cele C. Otnes, and Linda Tuncay (2007), "Pursuing Parenthood: Integrating Cultural and Cognitive Perspectives on Persistent Goal Striving," Journal of Consumer Research, 34 (December), 425-40.

Fitzsimons, Gavan J. and Donald R. Lehman (2004), "Reactance to Recommendations: When Unsolicited Advice Yields Contrary Responses," Marketing Science, 23 (1), 82-94.

Foucault, Michel (1984), "On the Genealogy of Ethics," in The Foucault Reader, ed. Paul Rabinow, New York: Pantheon, 340-72.

- (1986), The Care of the Self: The History of Sexuality, Vol. 3, New York: Random House.

Girard, René (1977), Violence and the Sacred, Baltimore: Johns Hopkins University Press. 
Goffman, Erving (1959), The Presentation of Self in Everyday Life, New York: Doubleday.

- (1963), Stigma: Notes on the Management of Spoiled Identity, New York: Simon \& Schuster.

Gökarıksel, Banu and Katharyne Mitchell (2005), "Veiling, Secularism, and the Neoliberal Subject: National Narratives and Supranational Desires in Turkey and France," Global Networks, 5 (2), 147-65.

Gökarıksel, Banu and Anna J. Secor (2009), “New Transnational Geographies of Islamism, Capitalism and Subjectivity: The Veiling-Fashion Industry in Turkey," Area, 41 (1), 6-18.

Göle, Nilufer (1996), The Forbidden Modern: Civilization and Veiling, Ann Arbor: University of Michigan Press.

- (2003), "The Voluntary Adoption of Islamic Stigma Symbols," Social Research, 70 (Fall), 809-27.

Goulding, Christina, Avi Shankar, Richard Elliott, and Robin Canniford (2009), "The Marketplace Management of Illicit Pleasure," Journal of Consumer Research, 35 (February), 759-71.

Gülalp, Haldun (1999), "Political Islam in Turkey: The Rise and Fall of the Refah Party," Muslim World, 89 (1), 22-41.

Henry, Paul Conrad and Mary Louise Caldwell (2006), "SelfEmpowerment and Consumption: Consumer Remedies for Prolonged Stigmatization," European Journal of Marketing, 40 (9-10), 1031-48.

Hill, Ronald Paul and Mark Stamey (1990), "The Homeless in America: An Examination of Possessions and Consumption Behaviors," Journal of Consumer Research, 17 (December), 303-21.

Holt, Douglas B. (1997), "Poststructuralist Lifestyle Analysis: Conceptualizing the Social Patterning of Consumption," Journal of Consumer Research, 23 (March), 326-50.

- (1998), "Does Cultural Capital Structure American Consumption?" Journal of Consumer Research, 25 (June), 1-25.

Hoodfar, Homa (1993), "The Veil in Their Minds and on Our Heads: The Persistence of Colonial Images of Muslim Women," Resources for Feminist Research, 22 (3-4), 5-18.

Ilmonen, Kaj (2001), "Sociology, Consumption and Routine," in Ordinary Consumption, ed. Jukka Granow and Alan Warde, London: Routledge, 9-23.

İlyasoğlu, Aynur (1994), Örtülü Kimlik, Istanbul: Metis.

Iyengar, Sheena S. and Mark R. Lepper (2000), "When Choice Is Demotivating: Can One Desire Too Much of a Good Thing," Journal of Personality and Social Psychology, 79 (6), 995-1006.

Kates, Steven M. (2002), "The Protean Quality of Subcultural Consumption: An Ethnographic Account of Gay Consumers," Journal of Consumer Research, 29 (December), 383-99.

Kentel, Ferhat (2004), “1990‘ların İslami Düşünce Dergileri ve Yeni Müslüman Entellektüeller,” in Modern Türkiye ‘de Siyasi Düşünce: İslamcılık, ed. Yasin Aktay, İstanbul: İletişim Yayınları, 721-81.

Keyman, Fuat (2007), "Modernity, Secularism and Islam: The Case of Turkey," Theory, Culture and Society, 24 (2), 215-34.

Kozinets, Robert V. (2001), "Utopian Enterprise: Articulating the Meaning of Star Trek's Culture of Consumption," Journal of Consumer Research, 28 (June), 67-89.

(2002), "Can Consumers Escape the Market? Emancipatory Illuminations from Burning Man," Journal of Consumer Research, 29 (June), 20-38.

Kozinets, Robert V. and Jay M. Handelman (2004), “Adversaries of Consumption: Consumer Movements, Activism, and Ideology," Journal of Consumer Research, 31 (December), 691-704.
Link, Bruce G. and Jo C. Phelan (2001), "Conceptualizing Stigma," Annual Review of Sociology, 27 (1), 363-85.

Loewenstein, George (2001), "The Creative Destruction of Decision Research," Journal of Consumer Research, 28 (December), 499-505.

Mahmood, Saba (2001), "Feminist Theory, Embodiment, and the Docile Agent: Some Reflections on the Egyptian Islamic Revival," Cultural Anthropology, 16 (2), 202-36.

Malti-Douglas, Fedwa (2001), Medicines of the Soul: Female Bodies and Sacred Geographies in a Transnational Islam, Berkeley: University of California Press.

Mardin, Şerif (1973), "Center-Periphery Relations: A Key to Turkish Politics?" Daedalus, 102 (Winter), 169-90.

Melucci, Alberto (1996), Challenging Codes: Collective Action in the Information Age, Cambridge: Cambridge University Press.

Mernissi, Fatima (1991), The Veil and the Male Elite, Reading, MA: Addison-Wesley.

Mick, David Glen (2008), "Degrees of Freedom of Will: An Essential Endless Question in Consumer Behavior," Journal of Consumer Psychology, 18 (1), 17-21.

Mittelstaedt, John (2002), "A Framework for Understanding the Relationships between Religions and Markets," Journal of Macromarketing, 22 (1), 6-18.

Muñiz, Albert and Thomas C. O'Guinn (2000), "Brand Communities," Journal of Consumer Research, 27 (March), 412-32.

Muñiz, Albert and Hope Schau (2005), "Religiosity in the Abandoned Apple Newton Brand Community," Journal of Consumer Research, 31 (March), 737-47.

Navaro-Yashin, Yael (2002), "The Market for Identities: Secularism, Islamism, Commodities," in Fragments of Culture: The Everyday of Modern Turkey, ed. Deniz Kandiyoti and Ayşe Saktanber, London: I. B. Tauris, 221-53.

O'Guinn, Thomas C. and Russell W. Belk (1989), "Heaven on Earth: Consumption at Heritage Village, USA," Journal of Consumer Research, 16 (September), 227-38.

Parker, Richard and Peter Aggleton (2003), "HIV and AIDS-Related Stigma and Discrimination: A Conceptual Framework and Implications for Action," Social Science and Medicine, 57 (1), 13-24.

Radway, Janice A. (1991), Reading the Romance, Chapel Hill: University of North Carolina Press.

Reckwitz, Andreas (2002), "Toward a Theory of Social Practices: A Development in Culturalist Theorizing," European Journal of Social Theory, 5 (2), 243-63.

Rozario, Santi (2006), "The New Burqa in Bangladesh: Empowerment or Violation of Women's Rights?" Women's Studies International Forum, 29 (4), 368-80.

Said, Edward (1978), Orientalism: Western Conceptions of the Orient, New York: Random House.

- (1993), Culture and Imperialism, New York: Vintage.

Saktanber, Ayşe (1994), "Becoming the 'Other' as a Muslim in Turkey: Turkish Women vs. Islamist Women," New Perspectives on Turkey, 11 (Fall), 99-134.

- (2002), Living Islam, London: I. B. Tauris.

Sandıkcı, Özlem and Güliz Ger (2007), "Constructing and Representing the Islamic Consumer in Turkey," Fashion Theory, $11(2-3), 189-210$.

Schouten, John (1991), "Selves in Transition: Symbolic Consumption in Personal Rites of Passage and Identity Reconstruction," Journal of Consumer Research, 17 (March), 412-25.

Schouten, John and James H. McAlexander (1995), "Subcultures of Consumption: An Ethnography of the New Bikers," Journal of Consumer Research, 22 (June), 43-61. 
Schwartz, Barry (2004), The Paradox of Choice, New York: HarperCollins.

Scott, Linda M. (2005), Fresh Lipstick: Redressing Fashion and Feminism, New York: Palgrave Macmillan.

Secor, Anna J. (2002), "The Veil and Urban Space in Istanbul: Women's Dress, Mobility and Islamic Knowledge," Gender, Place and Culture, 9 (1), 5-22.

Sheth, Falguni A. (2006), "Unruly Muslim Women and Threats to Liberal Culture," Peace Review, 18 (4), 455-63.

Slater, Don and Fran Tonkiss (2001), Market Society: Markets and Modern Social Theory, Cambridge: Polity.

Tepper, Kelly (1994), "The Role of Labeling Processes in Elderly Consumers' Responses to Age Segmentation Cues," Journal of Consumer Research, 20 (March), 503-19.

Thompson, Craig J. (2004), "Marketplace Mythology and Discourses of Power," Journal of Consumer Research, 31 (June), $162-80$.

- (2005), "Consumer Risk Perceptions in a Community of Reflexive Doubt," Journal of Consumer Research, 32 (September), 235-48.

Thompson, Craig J. and Gökçen Coşkuner-Ballı (2007), “Countervailing Market Responses to Corporate Co-optation and the Ideological Recruitment of Consumption Communities," Journal of Consumer Research, 34 (August), 135-52.

Thompson, Craig J. and Diana L. Haytko (1997), "Speaking of Fashion: Consumers' Uses of Fashion Discourses and the Appropriation of Countervailing Cultural Meanings," Journal of Consumer Research, 24 (June), 15-42.

Thompson, Craig J., William B. Locander, and Howard R. Pollio (1990), "The Lived Meaning of Free Choice: An ExistentialPhenomenological Description of Everyday Consumer Experiences of Contemporary Married Women," Journal of Consumer Research, 17 (December), 346-61.

Toprak, Binnaz (1984), "Politicisation of Islam in a Secular State: The National Salvation Party in Turkey," in From Nationalism to Revolutionary Islam, ed. Said Amir Arjomand, New York: SUNY Press, 119-33.

Turner, Brian (1994), Orientalism, Postmodernism and Globalism, London: Routledge.
Üstüner, Tuba and Douglas B. Holt (2007), "Dominated Consumer Acculturation: The Social Construction of Poor Migrant Women's Consumer Identity Projects in a Turkish Squatter," Journal of Consumer Research, 34 (June), 41-56.

Venkatesh, Alladi and Lisa Penãloza (2006), "From Marketing to the Market," in Does Marketing Need Reform? Fresh Perspectives on the Future, ed. Jagdish N. Sheth and Rajendra Sisodia, New York: M. E. Sharpe, 134-50.

Vertigans, Stephan (2003), Islamic Roots and Resurgence in Turkey: Understanding and Explaining the Muslim Resurgence, Westport, CT: Praeger.

Walker, Dionne (2008), "GA Judge Jails Muslim Woman over Head Scarf," http://www.foxnews.com/wires/2008Dec17/0 ,4670,MuslimHeadscarfArrest,00.html.

Warde, Alan (2005), "Consumption and Theories of Practice," Journal of Consumer Culture, 5 (2), 131-53.

Watson, Helen (1994), "Women and the Veil," in Islam, Globalization and Postmodernity, ed. Akbar Ahmed and Hastings Donnan, London: Routledge, 141-59.

White, Jenny B. (2002), Islamist Mobilization in Turkey: A Study in Vernacular Politics, Seattle: University of Washington Press.

Wiktorowicz, Quintan (2004), Islamic Activism: A Social Movement Theory Approach, Bloomington: Indiana University Press.

Wong, Nancy and Tracey King (2008), "The Cultural Construction of Risk Understandings through Illness Narratives," Journal of Consumer Research, 34 (February), 579-94.

Yavuz, Hakan (2004), "Opportunity Spaces, Identity, and Islamic Meaning in Turkey," in Islamic Activism: A Social Movement Theory Approach, ed. Quintan Wiktorowicz, Bloomington: Indiana University Press, 270-87.

Yeğenoğlu, Melda (1998), Colonial Fantasies: Towards a Feminist Reading of Orientalism, Cambridge: Cambridge University Press.

Zuhur, Sherifa (1992), Revealing Reveiling: Islamist Gender Ideology in Contemporary Egypt, Albany, NY: SUNY Press. 